CESIS Electronic Working Paper Series

Paper No. 416

\title{
A survey of empirical studies using transaction level data on exports and imports
}

Joachim Wagner

July, 2015 


\title{
A survey of empirical studies using transaction level data on exports and imports
}

\author{
Joachim Wagner \\ Leuphana University Lueneburg and CESIS, KTH Stockholm \\ wagner@leuphana.de
}

[This version: June 11, 2015]

\begin{abstract}
This paper presents a tabular survey of 146 empirical studies for 39 countries, plus 8 studies for multiple countries, that use transaction level data on exports or imports of firms. I hope this survey is useful for readers who want to get an impression of the huge number of different topics that have been investigated with transaction level data for a large number of countries already; who want to learn whether transaction level data have already been used for a particular (maybe, their own) country, by whom they have been used to investigate which topics, and what the important results found are; who have access to transaction level data and an idea how to use them, and who want to find out whether others pursued the same or a similar topic already; who want to compare results from their own study based on transaction level data to results from other (similar, neighbor) countries and who are looking for suitable studies; who have access to transaction level data and who are looking for studies based on data from other countries that they can replicate with their data to uncover and investigate differences across countries, or to contribute to the unravelling of stylized facts that hold across countries (and time).
\end{abstract}

Keywords: exports; imports; transaction level data; literature survey

JEL codes: F14 


\section{Motivation}

When economists discovered that trade is performed by firms, and not by countries or industries, following the pioneering empirical paper by Bernard and Jensen (1995) for the U.S., hundreds of studies looked at firm level data from many different countries to investigate "Who trades? " and the closely related question "Who trades how much?". The focus of the early papers in this literature has been on "Who exports? What distinguishes exporters and non-exporters? How are exports linked to firm performance?" with a special view on the links between exports and productivity (see Wagner (2007) for a survey). Later the scope of studies on trade that use firmlevel data widened to ask "Who imports? What distinguishes importers and nonimporters? How are imports linked to firm performance? ", and the links between trade and other dimensions of firm performance besides productivity (including profitability, wages, and firm survival) were investigated (see Wager (2012d) for a survey). In this literature a typical data set used is based on either census-type data collected regularly by official statistics or on large comprehensive surveys of firms from other sources. We learned a lot from these empirical studies, and this literature inspired a new branch of theory named the "new new trade theory" with a focus on international activities of heterogeneous firms that was pioneered by Melitz (2003); see Melitz and Redding (2014) for a survey.

A new generation of empirical studies on foreign trade goes one step further by asking not only "Who trades how much?" but "Who trades how much of which goods (or services) with whom?" The data used in these studies are based on records of (legal) cross-border transaction regularly collected by the customs. The unit of observation in these data is a single transaction between economic agents located in two countries, e.g. the export of 15.234 tons of good A with a value of 124,756 Euro from Germany to China. The record of the transaction usually includes 
a firm identifier (tax registration number) of the exporting (or importing) firm. Using this identifier information at the transaction level can be aggregated at the level of the trading firm to generate period-firm-product-value-weight-destination (or -origin) data. These data show who trades how much of which good with customers (or suppliers) from which country in a given period (a year, or a month). Products are distinguished according to very detailed classifications, and the recording of value and weight allows the easy calculation of unit values that act as proxy variables for prices or indicators of quality. These transaction data can be linked over time to form panel data. Furthermore, the data can be linked to firm level data that has information on firm characteristics that is not included in the customs data, e.g. balance sheet data and data from regular surveys of the statistical offices.

Compared with the census-type data used in the earlier literature these transaction-level based data allow the researcher to look not only at one extensive margin of trade (participation in exporting, or importing), but at two more extensive margins, the number of goods traded and the number of countries traded with. These margins, and their links with characteristics of the firm and dimensions of firm performance, are investigated in a new and rapidly emerging literature that is surveyed in this paper.

Findings of empirical studies are summarized under seven topics that cover the role of "superstars" in trade; the average number of goods traded and countries traded with; the dynamics of trade in the short run; new insights on the links between firm characteristics and the extensive margins of trade; quality of traded goods and the number of goods and partner countries; evidence on hitherto undocumented types of foreign trade activities; and econometric tests of implications of models of multi-product, multi-destination exporters. 
I hope this survey is useful for readers who want to get an impression of the huge number of different topics that have been investigated with transaction level data for a large number of countries already; who want to learn whether transaction level data have already been used for a particular (maybe, their own) country, by whom they have been used to investigate which topics, and what the important results found are; who have access to transaction level data and an idea how to use them, and who want to find out whether others pursued the same or a similar topic already; who want to compare results from their own study based on transaction level data to results from other (similar, neighbor) countries and who are looking for suitable studies; who have access to transaction level data and who are looking for studies based on data from other countries that they can replicate with their data to uncover and investigate differences across countries, or to contribute to the unravelling of stylized facts that hold across countries (and time).

The rest of the paper is organized as follows. Section 2 presents a tabular synopsis of empirical studies by country, topic, and important findings. Section 3 comments on the lessons we learned from this new literature so far. Section 4 concludes with suggestions for future research.

\section{Empirical studies using transaction level data on foreign trade of firms}

The appendix to this paper includes a table with a tabular survey of 146 empirical studies for 39 countries plus 8 studies that cover multiple countries, that use transaction level data on exports or imports of firms. This survey is limited it two ways. It covers only papers that are written in English, and that use data on crossborder transactions with detailed information on the products traded and the countries of destination or origin. While the first selection criterion is, hopefully, not too restrictive, the second might be considered to lead to an exclusion of important 
papers that look at who trades what with whom based on data from surveys of firms (like the papers by Lawless (2009) or lacovone and Javorcic (2010)) or on information derived from records of foreign trade activities that were matched to firmlevel survey data (like in Castellani, Serti and Tomasi (2010)). This focus of the survey, however, seems adequate given the now large number of papers that use "true" transaction level data from countries all over the world.

\section{Lessons learned}

Empirical analyses that use transaction level data for exports and (to a much lesser extent) imports are available for a large number of countries from all over the world. While many papers deal with a singular, special topic, some cover common ground and uncover new results that can be considered as stylized facts that tend to hold over space and time. This section summarizes the findings of studies under seven topics that cover the role of "superstars" in trade; the average number of goods traded and countries traded with; the dynamics of trade in the short run; new insights on the links between firm characteristics and the extensive margins of trade; quality of traded goods and the number of goods and partner countries; evidence on hitherto undocumented types of foreign trade activities; and econometric tests of implications of models of multi-product, multi-destination exporters.

\subsection{Exports and imports are dominated by "superstars" trading many goods with many countries}

The top 1 percent of exporters - the so-called 'export superstars' - tend to dominate exports, and to cover the lion's share of all exports. This fact is documented by Freund and Pierola (2012) for 32 countries based on data from the World Bank Exporter Dynamics Database (EDD), and it is found in several other studies for 
countries not covered in the EDD (including Germany; see Wagner 2012a). A similar high degree of concentration has been documented for importers in several countries, including Belgium (Muuls and Pisu 2009), China (Manova and Zhang 2009), Germany (Wagner 2012a), Norway (Bernard, Moxnes and Ultveit-Moe 2013) and the USA (Bernard, Jensen and Schott 2009). These superstars trade many products with many countries of destination and origin.

\subsection{Most firms trade a small number of goods with a small number of countries}

While a few large firms trade a large number of goods with many countries, the bulk of firms export to and import from a small number of countries, and they trade a small number of goods only. This fact is documented for a number of countries, including Belgium (Muuls and Pisu 2009), Denmark (Eriksson, Smeets and Warzynski 2009), France (Eaton, Kortum and Kramarz 2004), Germany (Wagner 2012b), the United States (Bernard, Jensen and Schott 2009) and for Brazil, Chile, Denmark and Norway (Arkolakis and Muendler 2013).

\subsection{New evidence on the dynamics of trade in the short run}

Transaction level data are used to document new facts on the dynamics of trade in the short run. Short-run dynamics of exports are dominated by the intensive margin; new exporters or firms that stop exporting are much less important for year-to-year changes in exports. Evidence on this is reported for Chile (Álvarez and Fuentes 2011, Álvarez and Sáez 2014), France (Bricogne et al. 2010), Germany (Wagner 2014c), Hungary (Muraközy 2012), Portugal (Amador and Opromolla 2010), Spain (De Lucio et al. 2011), Turkey (Cebeci and Fernandes 2015), USA (Bernard, Jensen, Redding and Schott 2009), and for 38 developing plus 7 developed countries by 
Cebeci et al. (2012). Similar results for imports are available for several countries, including Argentina (Gopinath and Neiman 2011), Germany (Wagner 2013b) and Spain (De Lucio et al. 2011).

Using data for Chile, Álvarez, Faruq and López (2010) report that an important fraction of firms start to export new products to new markets each year. Previous experience in exporting a certain product, or exporting to a certain market, increases the probability to export these products to new markets, or new products to the same markets. Again for Chile, Blum, Claro and Horstmann (2013) find that one third of exporters enter into and exit from exporting multiple times, and that most continuing exporters enter and exit specific export destinations multiple times. Rahu (2015) report that in Estonia adding and dropping new products in exports is rife, about half of all firms change their export portfolio annually. Similarly, Buono and Fadinger (2012) find that export relationships are highly dynamic in France, where a large fraction is created and concluded each year. For Hungary, Békés and Muraközy (2012) report that about one third of firm-destination and about one half of firmproduct-destination export spells are temporary only. Amador and Opromolla (2010) document frequent switching of products and destinations by firms. Similarly, Damijan, Konings and Polanec (2014) report that in Slovenia the average firm changes about one-quarter of imported and exported product-markets every year. For Spain, Esteve-Pérez, Requena-Silvente and Pallardó-Lopez (2013) find that, while the firm export status is highly persistent, firms' destination portfolio is very dynamic with a median duration of firm-country exporting relationship of two years, but the risk of exiting sharply falls afterwards.

These findings based on transaction level data point to an enormous amount of heterogeneity in the short-run dynamics of exports that is hidden behind the veil of the more aggregate data used in earlier empirical investigations. 


\subsection{New insights on the links between firm characteristics and extensive margins of trade}

Detailed information on the number of goods traded and the number of countries traded with reveal new insights on the links between firm characteristics and the extensive margins of trade. Cases in point include productivity, credit constraints, firm age, innovation, and profitability.

Productivity is not only positively related to export participation, but to the other extensive margins of exports (the number of goods exported, and the number of export destination countries), too. Evidence is reported in studies for a number of countries, including Belgium (Bernard, Van Beveren and Vandenbussche 2014), Colombia (Casas, Diez and González 2015), Germany (Wagner 2012c) and Sweden (Andersson, Lööf and Johansson 2008). Similar results are reported for imports to, among others, Belgium (Muuls and Pisu 2009), Germany (Wagner 2012c) and Sweden (Andersson, Lööf and Johansson 2008).

Note that although there is a strong positive link between productivity and the extensive margins of exports Wagner (2013a) reports that German low-productive exporters are not marginal exporters defined according to the number of goods exported or the number of countries exported to. These low-productive exporters are competitive because they export high-quality goods (Wagner 2014a).

As regards credit constraints, it is well known that exporting firms are less financially constrained than non-exporting firms (see Wagner (2014e) for a survey of the literature), and similar evidence is reported in the few studies that look at credit constraints and imports (see Wagner 2015a). Using transaction level data for Belgium, Muuls (2015) reports that firms with lower credit constraints export more products and to a larger number of destinations, too, while this link shows up only for the number of products in imports. Manova, Wei and Zhang (2013) show that in 
China financial frictions restrict exporters' product scope, the number of export destinations, and the trade volume within each destination-product market. With German data Wagner (2015d) finds that credit constraints have a negative impact on both the number of goods exported and the number of export destination countries. In a companion paper Wagner (2015a) reports that a better credit rating score is positively related to the extensive margins of import; firm with a better score import more goods and source from more countries of origin.

The positive link between firm age and participation in international trade has been documented before. Transaction level data shed new light on this issue. Bastos and Dias (2013) report that in Portugal the distribution of the number of export destinations and exported products shift progressively to the right with firm age. Similarly, Wagner (2015b, 2015c) shows that in Germany older firms export and import more different goods to and from more different countries.

It is well documented in the literature that innovative firms are more likely to export, Using transaction level data from Hungary Halpern and Muraközy (2012) show that innovative firms export more products to more countries, too.

The links between the extensive margins of trade and firm profitability have been investigated with transaction level data for German firms. Wagner (2014f) reports that profits tend to be larger in firms with less diversified export sales over goods and in firms with more diversified export sales over destination countries. As regards imports, profits are not higher in firms that import more goods and from more countries; the productivity advantages of importers with large extensive margins are eaten up by extra costs related to buying more goods in more countries. 


\subsection{Quality of traded goods and extensive margins of trade}

Transaction level data usually have information on the value of a transaction and on the weight of the goods shipped. By dividing value and weight so-called unit values are computed. While unit values are not a perfect measure for the quality of traded goods, at least if the industry is controlled for at a detailed level of disaggregation, they serve as a suitable proxy variable. As Feenstra and Romalis (2014, p. 477) recently put it: "The unit values of internationally traded goods are heavily influenced by quality." These unit values have been used to investigate empirically the link between the quality of exported goods and the distance to destination countries. For Germany Wagner (2014h) finds that quality and distance to destination are not positively correlated. Wagner (2014b) reports that in Germany exporters of highquality goods tend to use high-quality inputs, and they are more profitable (Wagner 2014d).

As noted, unit values are only an indicator for the quality of the products traded. Two studies with data from France recently used the detailed information on the traded products from transaction level data to measure product quality more directly. Duvalaix-Treguer et al. (2015) look at firms that export cheese or cream. They merge the export transaction data with information from a list of firms and products concerned by protected designations of origin (PDO) to investigate the impact of the quality label on firms' export competitiveness in the cheese and cream industry. They find that PDO labelling has a positive impact on the number of destinations exported to. Martin and Mayneris (2015) merge transaction level data on exports with information from the Comité Colbert list of firms from the French luxury products sector to identify high-end variety exporters and to investigate the relation between quality and margins of exports. They report that high-end variety exporters 
do not export to more countries, but export to more distant destinations; in contrast to low end exporters, distance has almost no effect on high-end variety export(er)s.

\subsection{Evidence on the existence of hitherto undocumented types of trade activities}

Transaction level data reveal the existence of types of trade activities that are hidden in the trade data collected in census-type firm level surveys. Bernard, Van Beveren and Vandenbussche (2010) document that a large majority of Belgian firms export products they do not produce - they are engaged in Carry-Along Trade (CAT). These CAT exports are concentrated in the largest and most productive firms. Empirical evidence for CAT is also reported by Abreha, Smeets and Warzynski (2013) for Denmark and by Lo Turco and Maggioni (2013) for Turkey. Damijan, Konings and Polanec (2013) find that in Slovenia on average 70 percent of all exporting firms engage in pass-on trade (POT), i.e. in simultaneous export and import of identical products. The use of POT is increasing in firm size, product diversification, multinational status, firm productivity and profitability.

\subsection{Econometric tests of implications of models of multi-product, multi- destination exporters}

While theoretical models of internationally trading firms usually consider firms that produce a single good that is exported or not, several models now investigate multiproduct firms that may export many goods to many destinations. Bernard, Redding and Schott (2011) develop a general equilibrium model of multi-product, multidestination firms with heterogeneity in ability across firms and in product attributes within firms. They test core implications of this model with transaction level data from the United States. In line with the model they find that firms exporting many products 
also serve many export destinations and export more of a given product to a given destination. Wagner (2012a) takes this model to German transaction level data and, in line with the model, finds that the number of products exported and the number of export destinations are positively and statistically highly significantly related with total exports, exports of the largest product across all markets, and productivity.

This illustrates that transaction level data have the potential to serve as a data base for econometric tests of implications of multi-product models. Furthermore, stylized facts revealed by working with transaction level trade data can inspire theoreticians to build models that fit these newly revealed facts.

\subsection{Final remarks}

Results from several empirical studies that are summarized in this section demonstrate that transaction level data on exports and imports should be considered as a highly useful addition to the box of tools of trade economists. Many studies illustrate that the value of these data for research can be increased substantially when they are augmented by information on firm characteristics that are not recorded by the customs, including balance sheet data and data from regular surveys by the statistical offices.

\section{Two suggestions for future research}

The empirical trade literature based on transaction level data grew exponentially over the recent years, and we learned a lot from these papers. However, there is plenty of scope for future research.

First and foremost, we do know much less about the extensive margins of imports, its determinants, and its role in the dynamics of trade, than about the respective margins of exports. Here, evidence for more countries is most welcome. It would be great if a 
project that is comparable to the World Bank Exporter Dynamics Database (Cebeci et al. 2012) could be realized for imports, too.

Second, many results reported in the literature refer to a single country, or to a very small number of countries, only. This offers plenty of opportunities for replication studies, keeping in mind that 'the credibility of a new finding that is based on carefully analyzing two data sets is far more than twice that of a result based only on one' (Hamermesh (2000, p. 376). Hopefully, this survey is helpful to guide interested researchers here.

\section{References}

Abreha, Kaleb Girma, Valérie Smeets, and Frédéric Warzynsky (2013): Coping with the Crisis: Recent Evolution in Danish Firms' International Trade Involvement, 20002010. Aarhus University Economics Working Papers 2013-15.

Álvarez, Roberto, Hasan Faruq, and Ricardo A. López (2010): Is Previous Export Experience Important for New Exports? Central Bank of Chile Working Paper 599.

Álvarez, Roberto and J. Rodrigo Fuentes (2011): Entry into Export Markets and Product Qualtiy. The World Economy 34, 1237-1262.

Álvarez, Roberto and Camila Sáez (2014): Post financial crisis and exports expansion: Micro-evidence from Chilean exporters. MPRA Munich Personal RePEc Archive Paper 60637.

Amador, Joao and Luca David Opromolla (2010): The Margins of Exports: Firms, Products and Destinations. Economics Bulletin (Banco de Portugal), Spring, 103119.

Andersson, Martin, Hans Lööf, and Sara Johansson (2008): Productivity and International Trade: Firm Level Evidence from a Small Open Economy. Review of World Economics 144 (4), 776-801. 
Arkolakis, Costas and Marc-Andreas Muendler (2013): Exporters and Their Products: A Collection of Empirical Regularities. CESifo Economic Studies 59 (2), 223-248.

Bastos, Paulo and Daniel A. Dias (2013): The life cycle of exporting firms. Mimeo.

Békés, Gábor and Balázs Murakösy (2012): Temporary trade and heterogeneous firms. Journal of International Economics 87, 232-246.

Bernard, Andrew B. and J. Bradford Jensen (1995): Exporters, jobs, and wages in U.S. Manufacturing: 1976-1987. Brookings Papers on Economic Activity, Microeconomics, 1, 67-119.

Bernard, Andrew B., J. Bradford Jensen, Stephen J. Redding, and Peter K. Schott (2009): The Margins of US Trade. American Economic Review Papers \& Proceedings 99 (2), 487-493.

Bernard, Andrew B., J. Bradford Jensen, and Peter K. Schott (2009): Importers, Exporters, and Multinationals. A Portrait of Firms in the U.S. that Trade Goods. In Timothy Dunne, J. Bradford Jensen, and Mark J. Roberts (Ed.), Producer Dynamics. New Evidence from Micro Data. Chicago and London: University of Chicago Press, p. 513-555.

Bernard, Andrew B., Andreas Moxnes, and Karen Helene Ulltveit-Moe (2013): Twosided Heterogeneity and Trade. Mimeo.

Bernard, Andrew B., Stephen J. Redding, and Peter K. Schott (2011): Multiproduct Firms and Trade Liberalization. Quarterly Journal of Economics 126 (3), 1271-1318.

Bernard, Andrew B., Ilke Van Beveren, and Hylke Vandenbussche (2010): Multiproduct exporters, carry-along trade and the margins of trade. National Bank of Belgium NBB Working Paper Series No. 203.

Bernard, Andrew B., Ilke Van Beveren, and Hylke Vandenbussche (2014): Multiproduct exporters and the margins of trade. Japanese Economic Review 65 (2), 142157. 
Blum, Bernardo S., Sebastian Claro, and Ignatius J. Horstmann (2013): Occasional and perennial exporters. Journal of International Economics 90 (1), 65-74.

Bricogne, Jean-Charles, Lionel Fontagné, Guillaume Gaulier, Daria Taglioni, and Vincent Vicard (2010): Exports and Sectoral Financial Dependence. Evidence on French Firms During the Great Global Crisis. European Central Bank Working Paper Series No 1227.

Buono, Ines and Harald Fadinger (2012): The micro dynamics of exporting: evidence from French firms. Banca D'Italia Temi di Discussione Number 880.

Casas, Camila, Federico J. Díez, and Alejandra González (2015): Productivity and Export Market Participation: Evidence from Colombia. Banco de la Republica Colombia, Borradores de Economía Núm. 876.

Castellani, Davide, Francesco Serti, and Chiara Tomasi (2010): Firms in International Trade: Importers' and Exporters' Heterogeneity in Italian Manufacturing Industry. The World Economy 33 (3), 424-457.

Cebeci, Tolga and Ana M. Fernandes (2015): Microdynamics of Turkey's Export Boom in the 2000s. The World Economy (in press).

Cebeci, Tolga, Ana M. Fernandes, Caroline Freund, and Matha Denisse Pierola (2012): Exporter Dynamics Database. World Bank Policy Research Working Paper 6229 .

Damijan, Joze P., Jozef Konings, and Saso Polanec (2013): Pass-on trade: why do firms simultaneously engage in two-way trade in the same varieties? Review of World Economics 149 (1), 85-111.

Damijan, Joze P., Jozef Konings, and Saso Polanec (2014): Import Churning and Export Performance of Multi-product Firms. The World Economy 37 (11), 1483-1506. 
De Lucio, Juan, Raúl Minguez-Fuentes, Asier Minondo, and Francisco RequenaSilvente (2011): The extensive and intensive margins of Spanish trade. International Review of Applied Economics 25 (5), 615-631.

Duvalaix-Treguer, Sabine, Charlotte Emlinger, Carl Gaigne, and Karine Latouche (2015): Quality and Export Performance: Evidence from cheese industry. Mimeo.

Eaton, Jonathan, Samuel Kortum, and Francis Kramarz (2004): Dissecting Trade: Firms, Industries, and Export Destinations. American Economic Review Papers \& Proceedings 94 (2), 150-154.

Eriksson, Tor, Valérie Smeets, and Frédéric Warzynski (2009): Small Open Economy Firms in International Trade: Evidence from Danish Transactions-level Data. Aarhus University Department of Economics Working Paper 09-7.

Esteve-Pérez, Silviano, Francisco Requena-Silvente, and Vincente J. Pallardó-Lopez (2013): The Duration of Firm-Destination Export Relationships: Evidence from Spain, 1997-2006. Economic Inquiry 51 (1), 159-180.

Feenstra, Robert C. and John Romalis (2014): International Prices and Endogenous Quality. Quarterly Journal of Economics 129 (2), 477-527.

Freund, Caroline and Martha Denisse Pierola (2012): Export Superstars. The World Bank Policy Research Working Paper 6222.

Gopinath, Gita and Brent Neiman (2011): Trade Adjustment and Productivity in Large Crises. National Bureau of Economic Research NBER Working Paper Series 16958. Halpern, László and Balázs Murakösy (2012): Innovation, productivity and exports: the case of Hungary. Economics of Innovation and New Technology 21 (2), 151-173. Hamermesh, Daniel S. (2000): The craft of labormetrics. Industrial and Labor Relations Review 53 (3), 363-380.

lacovone, Leonardo and Beata S. Javorcik (2010): Multi-product exporter: Product churning, uncertainty and export discoveries. Economic Journal 120 (May), 481-499. 
Lawless, Martina (2009): Firm export dynamics and the geography of trade. Journal of International Economics 77 (2), 245-254.

Lo Turco, Alessia and Daniela Maggioni (2013): CAT exports in Turkish manufacturing. Mimeo.

Manova, Kalina, Shang-Jin Wei, and Zhiwei Zhang (2013): Firm Exports and Multinational Activity under Credit Constraints. Mimeo.

Manova, Kalina and Zhiwei Zhang (2009): China's Exporters and Importers: Firms, Products and Trade Partners. National Bureau of Economic Research NBER Working Paper Series 15249.

Martin, Julien and Florian Mayneris (2015): High-end variety exporters defying gravity: Micro facts and aggregate implications. Journal of International Economics $96(1), 55-71$.

Melitz, Marc J. (2003): The impact of trade on intra-industry reallocations and aggregate industry productivity. Econometrica 71 (6), 1695-1725.

Melitz, Marc J. and Stephen J. Redding (2014): Heterogeneous Firms and Trade. Handbook of International Economics, Volume 4, 1-54.

Muraközy, Balázs (2012): Margins of Hungarian exports during crisis. EFIGE working papers 53.

Muuls, Mirabelle (2015): Exporters, importers and credit constraints. Journal of International Economics 95 (2), 333-343.

Muuls, Mirabelle and Mauro Pisu (2009): Imports and Exports at the Level of the Firm: Evidence from Belgium. The World Economy 32 (5), 692-734.

Rahu, Siim (2015): The Role of Uncertainty for Export Survival: Evidence from Estonia. The University of Tartu FEBA Working Paper.

Wagner, Joachim (2007): Exports and productivity: A survey of the evidence from firm-level data. The World Economy 30 (1), 60-82. 
Wagner, Joachim (2012a): German multiple-product, multiple destination exporters: Bernard-Redding-Schott under test. Economics Bulletin 32 (2), 1708-1714.

Wagner, Joachim (2012b): Trading many goods with many countries: Exporters and Importers from German manufacturing industries. Review of Economics 63 (2), 170186.

Wagner, Joachim (2012c): Productivity and the extensive margins of trade in German manufacturing firms: Evidence from a non-parametric test. Economics Bulletin 32 (4), 3061-3070.

Wagner, Joachim (2012d): International trade and firm performance: a survey of empirical studies since 2006. Review of World Economics 148 (2), 235-267.

Wagner, Joachim (2013a): Are low-productive exporters marginal exporters? Evidence from Germany. Economics Bulletin 33 (1), 467-481.

Wagner, Joachim (2013b): Extensive margins of imports in the great import recovery in Germany, 2009/2010. Economics Bulletin 33 (4), 2732-2743.

Wagner, Joachim (2014a): Low-productive exporters are high-quality exporters. Evidence from Germany. Economics Bulletin 34 (2), 745-756.

Wagner, Joachim (2014b): What makes a high-quality exporter? Evidence from Germany. Economics Bulletin 34 (2), 865-874.

Wagner, Joachim (2014c): The Role of Extensive Margins of Exports in The Great Export Recovery in Germany, 2009/2010. Jahrbücher für Nationalökonomie und Statistik / Journal of Economics and Statistics 234 (4), 518-526.

Wagner, Joachim (2014d): Exports and firm profitability: Quality matters! Economics Bulletin 34 (3), 1644-1652.

Wagner, Joachim (2014e): Credit constraints and exports: a survey of empirical studies using firm-level data. Industrial and Corporate Change 23 (6), 1477-1492. 
Wagner, Joachim (2014f): Is export diversification good for profitability? First evidence for manufacturing enterprises in Germany. Applied Economics 46 (33), 4083-4090.

Wagner, Joachim (2014h): A note on quality of a firm's exports and distance to destination countries: First evidence from German. University of Lüneburg Working Paper Series in Economics No. 302.

Wagner, Joachim (2015a): Credit constraints and margins of import: first evidence for German manufacturing enterprises. Applied Economics 47 (5), 415-430.

Wagner, Joachim (2015b): A note on firm age and the margins of imports: first evidence from Germany. Applied Economics Letters 22 (9), 679-682.

Wagner, Joachim (2015c): A Note on Firm Age and the Margins of Exports: First Evidence from Germany. The International Trade Journal 29 (2), 93-102.

Wagner, Joachim (2015d): Credit constraints and the extensive margins of exports: First evidence for German manufacturing. University of Lüneburg Working Paper Series in Economics No. 336. 
Appendix

(For online publication only) 


\section{Appendix: Tabular survey of empirical studies using transaction level data on exports and imports}

\section{Country}

Author(s)

Data

Topics

Important findings

(Year)

\section{Argentina}

Gopinath and

Neiman

(2011)

1996-2008; universe of import

transactions (name of firm, source

country, quantity, weight, price,

value and HS10 good), matched

with firm characteristics for largest

firms

Albornoz, Calvo Pardo, 2002-2007; all manufacturing

Corcos and Ornelas

(2012)

exporters; annual value of foreign

sales by country of destination

Brambilla, Lederman and Porto

1998-2000; total value of exports by country of destination at firm level, matched with data from firm survey on various characteristics

\section{Belgium}

Muuls

(2008)
1999-2005; firm exports by valuedestination-product; merged with firm characteristics and credit rating score
Trade adjustment during the Argentine crisis

Sequential exporting - entry, survival and/or exit on export destination markets; development of theoretical model and test

Investigation of links between exports, export destinations, and skill utilization

Interaction between credit constraints and exporting behavior
Small role of extensive margin (entry and exit of firms or of products at the country level); large role of churning of inputs within firms; relative importance of margins and of overall trade adjustment varies with firm size.

Growth of a firm's exports highest early in its first foreign market; new exporters more likely to enter new foreign markets; new exporters more likely to exit a market.

Firms exporting to high-income countries hired more skilled workers than other exporters and domestic firms. No causal effect of exporting per se on skill utilization,

Firms with higher productivity and lower credit constraints more likely to be exporting; credit constraints important in determining the extensive but not the intensive margin of trade in terms of destinations. 
1996-2004; firm exports and imports by destination/origin and product; merged with firm characteristics

Bernard, Van Beveren 1998-2005; exports by product and Vandenbussche (2010) and destination plus firm-level characteristics

\section{Cuyvers, Dhyne and Soeng}

Mion and Zhu

Amiti, Itskhoki and Konings

(2012)
1997-2007; exports and imports by products and country of destination or origin; matched with balance sheet data, data on FDI and data on wages and employment by type of workers

1995-2007; imports by firm-yearproduct(CN8)-country; matched with balance sheet data

2000-2008; product (CN8), exports by destination, imports by source country
Extent of within-industry job reallocation from firms with / without involvement in international markets

Causal effects of exports to different destination countries

Offering a complete view of the international trading activities of firms

\section{Examination of multi-product} exporters, relation between margins of trade and firm productivity

Effects of internationalization on domestic demand for production and non-production workers through foreign trade or outward FDI in highincome and low-income countries

Impact of imports from different origins on firm growth, exit, and skill upgrading

Exchange rate disconnect - why do large movements in exchange rates have small effects on prices of Internationally traded goods?
Shifts in employment between firms having different trading status account for 6 to 30 percent of total job reallocation; effect stronger for large than for small firms.

Productivity advantage of firms exporting to developed countries appears to be driven solely by self-selection.

Imports and exports strongly concentrated among largest and most productive firms. Most firms export to and import from small number of countries; same at product level.

Large majority of Belgian firms export products they do not produce, i.e. Carry-Along Trade (CAT). CAT exports concentrated in the largest and most productive firms.

Increasing import shares from low-income countries or investing in those countries significantly reduces demand for low-skilled labor, while it increases demand for skilled labor. Increase in exports raises (reduces) demand for production (non-production) workers, but effects are reversed in case of exports to low-income countries.

China is different from both other low-wage and OECD countries; industry-level import competition and firmlevel outsourcing to China reduce firm employment growth and induce skill upgrading.

More import-intensive exporters have significantly lower exchange-rate pass-through into their export prices, as they face offsetting exchange rate effects on their marginal costs. 

transactions of goods and services at month-year-firm-product(service)country level

Behrens, Corcos and Mion

(2013)

Schminke and Van Biesebroeck (2013)

Bernard, Van Beveren 1998-2005; data on export and Vandenbussche transactions plus firm-level (2014) characteristics on exports

Muuls

(2015)

1999-2007; exports and imports at firm level by value, destination/ origin and product (HS8); merged with firm characteristics and credit rating score

\section{Brazil}

\section{Arkolakis} and Muendler (2010)
-2009; exhaustive data on exports and imports by firm-countryproduct matched with balance sheet

weight and exports by product, value, firm characteristics and information on export assistance received
Comparison between trade in goods and trade in services

Trade collapse in 2008-2009

Success of export promotion in improving export performance, in particular propensity to export

\section{Examination of multi-product} exporters

Interaction between credit constraints and exports/imports, looking at extensive and intensive margins

Documentation of set of regularities for multi-product exporters; development of theoretical model
Many facts on trade participation, firms' characteristics, trade margins at the firm level (number of products, number of countries, number of transactions, average transaction size); high degree of concentration; entry, exit and survival in foreign markets; growth strategies and geographic patterns.

Belgian exports and imports mostly fell due to smaller quantities sold and unit prices charged rather than fewer firms, trading partners, and products in trade.

Export promotion increases export propensity; promotion more effective in reaching destinations outside the single market. Experienced exporters benefit on product- and destination extensive margin, and on intensive margin.

Exports highly concentrated in few firms. More productive firms export more products to more countries and have higher average product-country export flows.

Firms with lower credit constraints more likely to export or import, and export and import more. For exports, credit constraints matter for number of products and number of destinations; for imports, only for number of products.

Few top-selling products account for bulk of firm's exports in a market; number of products per firm in a market similar across markets and positively associated with average sales per product within each market; firms export their highest-sales products across multiple destinations. 
Molina and

Muendler

(2013)

Chile

Blum, Claro

and Horstmann

Blum, Claro

and Horstmann

(2010)

Àlvarez, Faruq

and López

(2010)
1990-2001; exports by firm, destination country and year matched with firm characteristics and data for all employees

2004-2006; matched data on all Chilean exporters with their Columbian importers at the

transaction leve

2004-2008; matched data on Chilean importers with their Argentine export partners at transaction leve
Firms' preparation for export by hiring of employees with prior

experience at other exporters

ocument basic characteristics of the ways trade is intermediated.

Provide a broader set of facts on trade intermediaries

991-2001; all manufacturing exporters Decision to start exporting a new Export transactions (value, weight, product-market pair product (HS8) and destination)
Expected exporter status leads firms to prepare their workforce by hiring workers from other exporters.

At least one of the trading parties is a large international trader. More than half exporters sell to only one importer

Small exporters from Argentina match typically with one large Chilean importer. Import intermediaries specialize in countries.

Enormous heterogeneity in terms of number of products and destination countries; important fraction of firms start to export new products to new markets each year; previous experience exporting a certain product, or exporting to a certain market, increase probability to export these product to new markets, or new products to same markets.

Large number of new exporting relationships each year representing small share of total exports; very low survival rates of new exporters; entry generally

\section{Fuentes}

1991-2001; all manufacturing exporters Evolution of unit values afte Export transactions (value, weight, export start or introduction of product (HS8) and destination) a new product-market combination associated with higher unit values.

Blum, Claro and Horstmann (2013)

\section{1-2008; export transactions} (firm, HS8, destination country, date, weight, quantity, value)
Document and model features of firms' export entry and exit behavior
One third of exporters enter into and exit from exporting multiple times; most continuing exporters enter and exit specific export destinations multiple times; firms re-entering exporting often sell the same product(s) to the same importer(s) 
Aisen, Àlvarez, Sagner and Turén (2013)

Àlvarez and Sáez (2014)

Blyde, Iberti and Mussini

\section{China}

Manova and Zhang

(2009a)

Manova and

Zhang

(2009b)

Mayneris and

Pocet

Roberts, Xu, Fan and Zhang

(2011)
2006-2009; all exporters, monthly information by product (HS8) and destination country

2007-2011; all exporters

Monthly information by product

(HS8) and destination country; value and weight of traded goods

2009; universe of exports, information on firm, goods (HS8), destination, value, quantity, unit price; matched with information on innovation activities in 2007/8 and other firm characteristics

2003-2005; firm exports and imports by product and destination/source country at monthly frequency, plus information on firm ownership structure

2005; universe of fob value of firm exports and imports by product (HS8) and destination/source country, plus quantities to construct unit values

1997-2007; export flows aggregated by province-year-product-destination

2002-2006; value and quantity of all footwear exporting transactions at 6-digit product level by destination; matched with firm characteristics
Establish novel and confirm existing stylized facts about firm heterogeneity in trade

Effect of the financial crisis on extensive and intensive margin of exports

Recovery of post-crisis exports

Relation between innovation and exports

Variation in export prices across firms, products and destinations to distinguish between alternative heterogeneous firm models of trade

Influence of the proximity to multinational exporters on the creation of new export linkages by domestic firms

How underlying firm heterogeneity on demand and production sides exporters influences long-run performance of
Larger exporters from industries more dependent on overall credit suffered disproportionally more in terms of export growth, but less in terms of entry and exit.

Intensive margin accounts for much of the dynamics of exports; large firms and firms with low dependency on external financing increased exports in recovery.

Innovative exporters outperform non-innovative exporters because they sell goods and target markets that reward innovation.
Bulk of trade done by few multiproduct multi-country traders; ownership structure matters for margins of trade; firms frequently exit and re-enter into trade and regularly change their product mix and trade partners; most export growth due to surviving exporters, etc.

Firms charging higher export prices earn larger revenues within each destination, have greater worldwide sales, and export to more markets; firms offer higher prices in larger, richer and more distant markets, etc

Domestic firms' capacity to start exporting new varieties to new markets positively responds to export activity of neighboring foreign firms for that same product-country pair.

Firm parameters from both demand and cost side of the firm's activities can be retrieved from micro data on firm production and export transactions; firm parameters useful in summarizing differences in firm export patterns across destination markets. 
Wang and $\mathrm{Yu}$ (2011)

Fan, Lai and

Amber

(2012)

Manova and

Yu

\section{Manova, Wei} and Zhang

Vannoorenberghe, Wang and $\mathrm{Yu}$

Yu and Li

(2014)
2002-2006; all exports and imports by firm,HS8 product, value, quantity, country of destination / origin, and trade regime (ordinary vs. processing); trade. matched with firm characteristics

2000-2006; universe of exports and imports (HS8 products, value, quantity, country, type of firm), matched with firm characteristics

2005; universe of trade transactions by firms, HS8-products and destination plus type of trade (ordinary, processing with imports, pure assembly), matched with balance sheet data and other firm characteristics

2005; universe of trade transactions by firms, HS8-products and destination; information on firm type (state-owned, private, foreignowned)

2000-2006; export by firm-HS8 product, value and quantity, country of destination; matched with firm characteristics

2002-2006; imports by firms and products (HS8, value and weight); matched with firm-level information
Links between firm performance and exports and imports, distinguishing

between ordinary and processing rade.

Relationship between credit constraints faced by a firm and the unit value prices of its exports, and between export prices and productivity

Role of financial constraints for choice of type of trade regime (ordinary vs. processing trade); consequences for profits

tefility and value added fall as exporters orient sales from ordinary towards processing trade, and from import-and-assembly towards pure assembly; less financially constraint firms perform more ordinary trade relative to processing trade, and more import-toassembly relative to pure assembly.

Impact of credit constraints on different Financial frictions restrict firm entry into exporting, as well trade margins as exporters' product scope, number of export destinations, and trade volume within each destinationproduct market. Foreign ownership mitigates these distortions.

Volatility and diversification of exports Among small exporters, firms selling to a more diversified set of countries have more volatile exports, while the opposite holds among large exporters.

Impact of imported intermediate inputs Firm productivity increases with increased imported on firms intermediate inputs; weaker impact as firms produce more complex products. 
Bai, Krishna and

$\mathrm{Ma}$

(2015)

\section{Colombia}

Eaton, Eslava, Kugler and Tybout

Tovar and

Martínez

(2011)

Molina and Roa

(2014)

Casas, Díez and González

(2015)

\section{Costa Rica}

Lederman Rodríguez-Clare and Yi Xu (2011)

2002-2006; universe of trade transactions by firms, product (HS8), destination/origin and value; matched with information on firm characteristics

1996-2005; universe of exports by firm, product, value and country of destination

2000-2008; exports by firm (product, value, destination)

1998-2006; for all exporting firms annual information on total value of exports, number of export destinations, number of exported products and

exports per destination; matched with firms' financial information and information on banks

2005-2013; annual information about exports (10digit product code, value of exports, country of destination); matched with detailed balance sheet and operational information

1997-2007; all firms with positive exports in the period; export values products, quantities, destination markets
Role of export mode (directly or indirectly via intermediaries)

Demand and productivity evolve more favorably under direct exporting, though the fixed/sunk costs of this option are higher.
Firm-specific export patterns over time (entry and exit into and out of destination markets; revenues from selling there)

Determinants of survival of firm in export market

\section{Credit elasticity of exports}

ship between total factor productivity and exporting decisions

Role of new exporters in export growth
Firms that export to a larger number of destinations and/or a larger number of goods tend to be more productive; no relationship between productivity and type of destination or exported product.

Large share of (small) firms enter and exit exports each year; export sales dominated by small number of very large and stable exporters. Successful new exporters from a cohort important after some years. New exporters start in one market and expand gradually.

Market diversification prevails over product diversification while trade network effects are highly correlated to survival of new exporting firms.

Access to credit produces a significant increase on a manufacturer's export revenue explained by the positive effect of credit on number of export destinations. Small manufacturers do not seem to benefit from bank credit.

High rate of firm turnover into and out of exporting each year; exiting and entering firms much smaller than incumbent exporters; new product-firm combinations highly important in the long run. 


\section{Denmark}

Eriksson, Smeets and Warzynsk (2009)

lbsen, Warzynski and Westergard-

Nielsen

Meinen

(2011)

Utar

Abreha, Smeets and Warzynski

(2013) source country; CN8, HS6)

1993-2003; all import and export transactions by firms (products CN8, value, quantity, country), matched with balance sheet information and data for all employees in the firms

1993-2003; values and quantities of import and export of goods at the firm level by product (CN8) and origin or destination; matched with firm characteristics

1995-2006; firm level data on exports and imports by market and HS8-product; merged with firm characteristics

1995-2007; textile and clothing industry firms; 8-digit product-firmdestination-year data on exports; matched with firm characteristics and data on individual employees

2000-2010; universe of firms export and Import transactions (value, weight, quantity; destination/ further firm level information matched

Smeets and Warzynski

(2013) (value, weight, quantity; destination/
1999-2006; universe of firms export and import transactions source country; CN8); matched with further firm level information
Detailed characterization of firms in international trade import decisions and employment growth

Role of destination market and product characteristics for sunk costs of exporting

Analysis of within firms adjustments to intensified low-wage competition due to dismantling of the Multi-fibre Arrangement quota system after China's WTO membership

Macro aspects of trade;

Firm participation in exports and imports

\section{of trade adjustment; small contribution of newly served}

Relationship between exports, imports and firm productivity taking into account pricing heterogeneity and multi-product firms few multi-good multi destination firms in exports; evidence for carry-along trade; small role played by entry and exits of firms or products as margin export destinations and exported products.

Exporters make up a fairly small fraction of all firms and have positive performance characteristics. Large share of two countries; most firms export few products to few countries

Imports and exports positively related to employment growth (both finished goods and intermediate goods).

unk costs mainly destination specific even though previous export experience from other markets facilitates entering new markets; sunk costs higher in developed markets and increase in export volume and firm size. Size heightened competition; firms refocus innovation efforts away from goods where China's competitive advantage increases.

Firm level price index to deflate output; comparison of productivity measures with results using industry-level deflator; large productivity premium for only-importers but larger for two-way traders; premia larger when firmspecific price index is used. largest exporters in total exports. Median firm exports to 


\section{Estonia}

\section{Masso and}

Vather

Rahu

(2015)

France

Kramarz

Eaton, Kortum

and Kramarz

(2004)

\section{Biscourp and}

Kramarz

(2007)
1998-2006; firm level data on trade (value, country of origin/destination, weight, CN8 product); matched with firm characteristics

1995-2003; population of exporters exports by firm, destination, product (CN8); matched with characteristics of firms

1995-2011; firm-product-destination level export data; customs data are merged with Business Registry data
Wholesale trade firms and their role in international trade

Role of different modes of export market entry for effects of exports on productivity

Role of initial product export share and product differentiation in
Export and import premia exist even among wholesale trade firms. survival of trade flows

Early stage entry into several export markets or with several products leads to higher growth in productivity, compared with entry into only one foreign market or with only one product.

Adding and dropping new products is rife, about half of all firms change their export portfolio annually. Surviva is better if initial export share is larger and exports are more differentiated. Previous experience with foreign markets and different products has positive impact.

Small negative effect of increased imports on employment; changes in skill structure as predicted

Relationship between importexport behavior of firms and their by trading firm (value) by destination or origin, but no information on goods traded; matched with firm and employee information

1986; exports by firms and country of destination

1986-1992; all international trade transactions plus firm level information labor market outcomes - employment, skill structure, wage structure, within firm inequality, and propensity to separate from workers

Establish some key features of the data

Analysis of links between imports exports, employment, and skill structure of manufacturing firms by trade theory, but small. No relation between wage probability of changing firm or losing one's job.

Modal exporter ships to only one foreign destination; exports by small fraction of firms that ship widely constitute substantial share of total exports.

Strong correlation between increasing imports, in particular imports of finished goods, and job destruction, most notably destruction of production jobs. evolution and trade behavior or individual-leve 
Berman, Martin and Mayer

Bas and

Strauss-Kahn

(2010)

Bricogne, Fontagné Gaulier, Taglioni and

Vicard

(2010)

Koenig, Mayneris and Poncet

Eaton, Kortum and

Kramarz

(2011)

Berman, Berthou and Héricourt

(2012)

Bourgeon, Bricogne and Gaulier (2012)
1995-2005; balance sheet data combined with firm-level export data value and volume by CN8 product and destination)

1995-2005; manufacturing firms. Firm characteristics matched with export and import data (products at HS6, countries

2000-2009; exports by firms on monthly basis, matched with financial information from Amadeus database

1998-2003; exports by firm, year product (HS8) and destination; matched with firm characteristic

1986; sales by firms and destination markets

1995-2001; balance-sheet data product-destination-specific export information

1999-2007; export transactions matched with corporate accounts data and data on payment incidents occurring at firm's partners
Reaction of exporters to exchange rate changes

Impact of imported inputs on margins of exports

Large drop in exports during last quarter of 2008 and first quarter of 2009

Presence of local export spillovers on decision to start to export and the volume of exports

Examination of sales by destination; develop theoretical model and estimated it to match moments of the data and use it in simulations

Are foreign and domestic sales complements or substitutes?

Analysis of combined effect of financial constraint and trading time on bilateral trade
High performance firms react to depreciation by increasing their export prices rather than their export volume; reverse is true for low productivity exporters. Probability of firms to enter export market increases after depreciation.

Higher diversification and increased number of imported inputs varieties have significant impact on firm's TFP and export scope. Effect larger for imports from developed countries with more technological content.

Drop in exports mainly due to intensive margin of large exporters. Small and large exporters evenly affected when sectoral and geographical specializations are controlled for.

Evidence of the presence of export spillovers on export decision but not on exported volume; effect stronger within employment areas and declines with Distance.

Number of firms selling to a market increases with market size; sales distributions similar across markets; average sales in France rise systematically with selling to less popular markets and to more markets.

Exogenous variations in foreign sales are positively associated with domestic sales, even after controlling for changes in domestic demand.

Trading time amplifies the negative effect of financial restrictions on trade. 
Buono and Fadinger (2012)

\section{Bernini, Guillou} and Bellone

(2013)

Berthou and

Fontagné

(2013)

Corcos, Irac, Mion and Verdier

Crozet, Lalanne and Poncet

(2013)

Mayer, Melitz and

Ottaviano

(2014)

\section{Berthou and}

Vicard

(2015)
1995-1999; exports by firms and destination in a year, combined with detailed balance-sheet information

1997-2007; firm characteristics plus export values, quantities, destination countries and products

1995-2003; annual export flow values of individual exports by product and destination

1999; imports by firm, origin country and product; by sourcing mode (arm's length vs. intrafirm)

2007; exports by goods, destination countries, value, weight, matched with balance sheet data

2003; firm level data on annual shipments by all exporters by all destinations by products (HS8)

1994-2008; export flows of all firms at monthly frequency (firm-product-country data)
Dynamics of export relationships (shipments by a given firm to a given destination in a given year)

Is corporate financial structure a determinant of non-price competitiveness in export markets?

How change in trade costs, following introduction of the Euro, affected export margins of firms in relation to export decision, number of products exported, and average sales per product

Choice between intrafirm and arm'slength trade in imports

Role of wholesalers in international trade

How competition across market destinations affects both a firm's exported product range and product mix

Importance of experience and size of exporters for their growth in foreign markets
Export relationships are highly dynamic (large fraction created / concluded each year); export values gradually increase as relationships mature; volatile and persistent relationships are found; previous exports to a destination substantially increase firm's probability to export there.

Among illiquid exporters leverage is negatively correlated with quality of their exported goods.

Firms increase range of exported products and their intensive margin; no evidence that firms increase their participation in the export market.

Intrafirm imports more likely in capital- and skill intensive firms, in highly productive firms, and from countries with well-functioning juridical institutions.

Wholesalers alleviate the difficulty of reaching lessaccessible markets; they help less-efficient firms to supply foreign markets.

Tougher competition in an export market induces a firm to skew its export sales toward its best performing products.

Conditional on size, the net export growth of surviving firms progressively declines with experience.

Gibrat's law holds for exports. Young exporters are more volatile in export markets. 
Duvalaix-Treguer et al. 2012; exports (value and quantity) (2015) by product (NC8) and destination; firms that export cheese or cream. Merged with information from list of firms and products concerned by protected designations of origin (PDO)

Martin and Mayneris 2000-2011; exports (value and

volume) at firm - CN8 - productcountry level; merged with information from Comité Colbert list of firms from the French luxury products sector

\section{Germany}

Stirböck and

Kähler

Wagner

(2012a)

Wagner

(2012b) and imports by firms (products, country of destination/origin) linked to information from the business register

2009; exports by firms; value value of largest product, number of different goods exported, number of destination countries; matched with firm characteristics

2009; exports and imports by firm; number of goods exported or
Impact of quality label (PDO) on firm export competitiveness in the cheese and cream industry

Identification of high-end variety exporters based on list of firms from the luxury sector; relation between quality and margins of export

Exploratory analysis of trading activities of firms within the EU imported, number of countries trades with, values of transactions: matched with firm characteristics

Econometric test of implications of theoretical model by Bernard, Redding and Schott (QJE 2011) and multi-country traders from manufacturing industries
PDO labelling has positive impact on number of destinations, value of trade and average export unit value; more important when exporting to EU countries.

High-end variety exporters do not export to more countries, but export to more distant destinations; in contrast to low end exporters, distance has almost no effect on high-end variety export(er)s.

Productivity premia for multi-product
Trade flows positive function of market size; positive association between productivity and imports or exports trade flows are a negative function of trade barriers.

Number of products exported and number of export destinations are positively and statistically highly significantly related with total exports, exports of the largest product across all markets, and productivity.

Firms that trade many goods or that trade with many countries are much more productive than firms of the same size from the same industry that trade some goods or trade with some countries only. 
2009; exports and imports by firms; number of different goods traded and number of countries traded with; matched with firm characteristics

2009; exports by firms; number of different goods exported and number of destination countries; matched with firm characteristics

2009-2010; imports by firms; value, number of different goods imported number of countries or origin

2009-2010; exports by firms; value and volume of exports for the ten most important exported goods: matched with firm characteristics

2009-2010; exports by firms; value and volume of exports for the ten most important exported goods; matched with firm characteristics

2009; exports by firms; number of goods exported and number of destination countries; matched with firm characteristics
Differences in productivity distributions The larger the number of goods exported or imported, of firms with different numbers of and the larger the number of countries exported to or traded goods and different numbers of imported from, the higher is the productivity of the firm countries traded with in manufacturing not only on average, but over the whole productivity industries distribution.

Are low productive exporters marginal Low-productive exporters are not marginal exporters exporters in manufacturing industries? defined according to the number of goods exported or the number of countries exported to.

Extensive margins of imports in the great import recovery of 2009/2010

Firms that imported in both 2009 and 2010 are much more important for import dynamics than import starters and stoppers; firms that increased their imports imported on average more goods and from more countries of origin in 2009 than firms that decreased their imports, and they increased both extensive margins of imports, while firms with decreased imports reduced both.

Low-productive exporters and quality of exported goods in manufacturing enterprises

Quality of exported goods and firm characteristics in manufacturing enterprises

Foreign ownership and the extensive margins of exports in manufacturing enterprises
Low-productive exporters are competitive because they export high-quality goods.

Exporters of high-quality goods tend to use high-quality inputs

Foreign-owned firms do export more goods to more countries after controlling for firm size, productivity and industry affiliation. 
number of destination countries

than firms that decreased their exports, and they

increased both extensive margins of exports,

Wagner

(2014d)

Wagner

(2014e)

Wagner

(2014f)

Wagner

Wagner

(2014h)
2009-2010; exports by firms; value and volume of exports for the ten most important exported goods;

matched with firm characteristics

2009-2010; imports by firms; number of goods imported and number of countries imported from; matched with firm characteristics

2009-2010; exports by firms; value and volume of exports for the ten most important exported goods matched with firm characteristics

2009-2011; imports by firms; value of imports; matched with enterprise characteristics

2010; exports by firms; value and volume of exports for the ten most important exported goods and ten most important destination countries; matched with firm characteristics and information on distance to export destinations
Extensive margins of exports in the great export recovery of 2009/2010

Quality of exported goods and profitability in manufacturing enterprises

Extensive margins of imports and profitability in manufacturing enterprises

Export diversification and profitability in manufacturing enterprises

Granular nature of imports in manufacturing sector

Quality of exported goods and distance to destination countries in manufacturing enterprises
Firms that exported in both 2009 and 2010 are much more important for export dynamics than export starters and stoppers; firms that increased their exports exported on average more goods and to more countries in 2009

while firms with decreased exports reduced both

Exporters of high-quality goods tend to be more profitable.

Profits not higher in firms that import more goods and from more countries; productivity advantages of importers with large extensive margins are eaten up by extra costs related to buying more goods in more countries.

Profits tend to be larger in firms with less diversified export sales over goods and in firms with more diversified export sales over destination countries.

Imports are power-law distributed, distributions in industries are fat-tailed; idiosyncratic shocks to very large firms important for import dynamics in 2010/2011 but not in 2009/2010.

Quality of exported goods and distance to destination countries are not positively correlated. 


\section{Georgia}

\section{Martuscelli and}

Varela

(2015)
2009-2010; imports by firms; value, number of different goods, number of countries of origin; matched with firm characteristics and credit rating score

2010; imports by firms; number of goods imported and number of countries imported from; matched with firm characteristics

2010; exports by firms; number of goods exported and number of countries exported to; ten most important countries of exports and value of exports to these countries; matched with firm characteristics and distance to destinations

2010; exports by firms; number of exported goods and number of destination countries; matched with firm characteristics

2009-2010; exports by firms; number of goods exported and number of destination countries: matched with firm characteristics and credit rating score

2006-2012; firm level data on all export transactions; matched with firm characteristics
Credit constraints and margins of imports in manufacturing

enterprises

Firm age and margins of imports

Firm age and margins of exports

Differences in extensive and intensive margins of exports in East and West German manufacturing enterprises

Credit constraints and extensive margins of exports in manufacturing enterprises

Determinants of export flow survival (role of firm level characteristics, diversification strategies, and network effects
Better credit rating score is positively related to extensive margins of import - firms with better score have higher probability to import, import more goods and source from more countries of origin. Share of imports in total sales is unrelated to credit constraints.

Older firms are more often importers, import more different goods, and import from more different countries of origin.

Older firms are more often exporters, export more and more different goods to more destination countries, and export to more distant destination countries.

West German firms outperform East German firms at all four margins of exports (propensity to export, share of exports in total sales, number of exported goods and number of destination countries).

Credit constraints have a negative impact on both the number of goods exported and the number of export destination countries.
Production efficiency, rather than size, boosts export survival chances; firms' diversification strategies matte for prospects of survival; strong evidence of network effects in export survival. 
Halpern, Koren and Szeid

Muraközy and

Békés

(2009)

Altomonte and

Békés

(2010)

Békés, Muraközy and Haraszosi

Halpern and

Murakösy

(2011)

Békés and

Muraközy

(2012)

Görg, Kneller and Muraközy

(2012)
1992-2001; trade data by

firm, product (HS6), value,

weight; merged with firm

characteristics

1992-2003; data for all trade transactions at the firm-productdestination leve

1992-203; manufacturing firms export and import transactions

(value, weight, quantitiy; destination/ source country; HS6)

1992-2003; almost universal panel of balance sheet information merged with firm-product-country level customs data

1992-2003; all exports by firm, product and destination country; merged with firm characteristics

1992-2003; data on all exports at firm-product-destination level; HS6 products

1992-2003; large exporting firms, exports and imports by product, value and weight; matched with firm characteristics
Effects of imports on productivity

Degree of stability of bilateral trade relationships

Relation between firms' trading activities (importing, exporting or both) and productivity

Detailed description of Hungarian trade data and key patterns drawn at the firm and product leve

Decomposition of export growth into number of firms, number of markets and products per firm by firm size

Stability of export spells at firmdestination and firm-destinationproduct level

Determinants of survival of products in the export mix of a firm
Positive impact of imports on productivity both statistically and economically significant.

Over half of non-zero bilateral trade relationships are of temporary nature, lasting for a short period only and disappearing in an erratic fashion; temporary Trade important for all kinds of firms and products.

Indicators of "trade complexity" correlated with ex-ante productivity of trading firms.

Trade concentration in Hungary slightly higher than in most European countries; foreign ownership and role of foreign firms in trade is higher. Hungarian trade activity broadly matches most open economy evidence.

Majority of small exporters exit exports after few years but survivors grow quickly in every dimension. Large exporters grow slowly; macro shocks, destination market and product heterogeneity strongly affect performance.

About one third of firm-destination and about one half of firm-product-destination export spells are temporary only. Likelihood of permanent trade rises with firm productivity, financial stability, proximity and GDP of destination countries.

Characteristics of the product as well as that of the firm matter in export dynamics; firm productivity, product scale and tenure associated with a higher export survival rate. 
Halpern and

Muraközy

(2012)

Muraközy

India

Goldberg, Khandewal, 1987-2000; import quantity and Pavnik and Topalova value by HS6 product

Goldberg, Khandewal, 1987-2000; import quantity and Pavnik and Topalova value by HS6 product, matched (2010) with firm characteristics

Italy

\section{Bernard, Grazzi} and Tomasi

(2011)

\section{Tamagn}

(2013) Community Innovation Survey data for 2002-2004

2008-2009; exports at firmproduct(HS8)-destination level statements annual value and quantity of destination pairs (HS6)

2000-2003; exports and imports
2003; data on all exports at firmproduct-destination level, linked to matched with firm-level financial

Analysis of decline of exports during the financial crisis on 2008-2009 by decomposition of fall of exports into intensive and extensive margins

Changes in the composition of import following 1991 trade liberalization to illustrate the potential scope for previously unavailable inputs to bolster performance of domestic firms

Relationship between decline in trade costs, imports of intermediate inputs, and domestic firm product scope

Factors that give rise to intermediaries in exporting and

implications for trade volumes exports for product-country by firm (value, weight, HS6 product, destination); matched with firm characteristics and credit rating index constraints and exports
Innovative firms more likely to export and export more products to more countries.

Only few firms exited from exports; fall of intensive margin responsible for about 80 percent of fall in exports; decline significantly larger for foreign-owned firms than for domestic firms.

Trade reform spurred imports of important newly available inputs for manufacturing firms from more advanced countries, and relaxed technological constraints faced by firms under import substitution policies.

Substantial gains from trade through access to new imported inputs; lower input tariffs account on average for $31 \%$ of new products introduced by domestic firms.

\section{Relationship between financia}

Intermediaries and direct exporters respond differently to exchange rate fluctuations; aggregate exports to destinations with high shares of indirect exports much less responsive to changes in real exchange rate.

Limited access to external capital narrows scale of foreign sales, exporters' product scope and number of trade partners; constraint firms have reduced probability of adding and higher probability of dropping products and destinations. 
Costa, Pappalardo and Vicarelli

Secchi, Tamagni and Tomasi

\section{Luxembourg}

Mangiarotti and

Schuller

(2010)

\section{Mexico}

\section{Giri, Seira and}

Teshima

(2013)

Netherlands

Creusen, Kox,

Lejour and Smeets

(2011)

Creusen and Lejour (2011)
2007 and 2010; exports and imports (goods, value and quantity and destination/origin country) matched with firm characteristics

2000-2003; exports and imports by product (HS6), value, weight and destination; matched with firm

characteristics and credit rating score

2004; firm level data for exports of goods (HS6) by destination country

2004-2010; exports to the U.S. by firm, product, value, price and quantity and year

2002-2007; countries, products volumes and prices by firms

2002-2008; country, product, value, volume by firms, matched with information on firm level and country level
Relationship between forms of internationalization and survival over the financial crisis

Role of financial constraints in shaping firms' export activities

Descriptive analysis of goods exports

How did small exporters fare relative to large exporters during the 2008-09 crisis?

Investigation of microeconomic patterns of Dutch exports

Export market entry decision of firms and their subsequent growth or market exit
Multinational firms show lower resilience during the crisis compared to global or two-way traders

imited access to external capital narrows scale of foreign sales, exporters' product scope and number of trade partners.

High concentration in exports value; high importance of multi-product, multi-destination exporters; negative relation between number of exporters and number of exported products and export destinations.

Crisis did not make smaller exporters more likely to exit, grow less, or expand their product line less.

Exports are heavily concentrated. Turbulence in extensive export margin quite substantial, mostly among small traders.

About $5 \%$ of exporters are starters or stoppers; many starters increase exports by expanding number of destinations. Firms seem to follow a stepping stone approach for reaching markets further away. 
Fabling and Sanderson

Fabling, Grimes and Sanderson (2012)

Norway

Moxnes

Bernard, Moxnes and Ulltveit-Moe

Peru

Volpe Martincus and Carballo

Freund and

Pierola

(2010)
2000-2006; shipment-level goods trade-data at firm level by product and country; matched with firm

characteristics

2002-2006; exports by goods and countries, matched with firm characteristics

1996-2006; export values by firm and destination country per year matched with firm characteristics

2005-2010; all exports by firmyear-product-value-quantitydestination plus identity of buyer

2001-2005; exports at firm-productdestination level; matched with firm characteristics and information on export promotion received

1994-2007; exports of firms from nontraditional agriculture sector by destination market, goods and value of shipment
Descriptive analysis with focus on role of novel exporting behavior

Product and market entry choices of exporters with regard to the next market served

Are sunk costs global or country specific?

Exploring the consequences of joint heterogeneity on the supply side (sellers) and the demand side (buyers); development of theoretical model with heterogeneous exporters and importers

Effectiveness of export promotion activities; links to extensive and intensive margins of firms' exports

Firm entry and survival in exporting, and in products and markets not previously served by any domestic exporter
Novel market entry is a significant contributor to aggregate export growth; much expansion in trade incremental in nature and risky, experience and scale appear to be key factors in overcoming these risks.

General and specific prior trade experience play important role in determining firms' future export activities, as do export activities of other firms in the local area.

Country-specific costs are about three times the magnitude of global costs; international standards harmonization strong positive effects on imported variety in small and remote markets.

Exports and imports highly concentrated, largest firms play dominant role; substantial variation of importer heterogeneity across markets. Larger sellers reach more customers and have more dispersion in sales across buyers.

Export promotion actions associated with increased exports, primarily along the extensive margin, both in terms of markets and products.

Significant entry and exit in new markets, but trial and error in new products rare. New products typically discovered by large experienced exporters. 
Bernard, Massari, Reyes and Taglioni (2013)

1992-2009; all shipments by month-product-destination country

\section{Portugal}

Martins and Opromolla

Amador and Opromolla

Bastos and Silva

\section{Mion and}

Opromolla

(2012)
1995-2005; all export and import transactions by firms, CN8 product code, value and quantitiy, country of destination/origin; matched with data for firm characteristic and data for all employees

\section{5-2005; universe of export} transactions (products (HS4), values, quantities, destination countries) by firms; monthly data

2005; exports by all firms to each of 220 destinations in over 7,500 product categories, linked to information on firm productivity and importing-country attributes

1995-2005; universe of export transactions at the firm-destinationyear level; matched with data on characteristics of firms and on all employees in the firms
Uncover size and consequences of partial-year effect of export entry

(when a firm does not enter in

January but later in the year) on

first year sales and growth in a marke

Effects of firm-level international trade on wages

Firm-level imports as important as exports for wages paid; firms that increase their exports (imports) of high- (intermediate-) technology products tend to increase salaries.

Description of joint destination/product High degree of firm heterogeneity; dominant role of strategies of exporters switching of products and destinations by firms. Intensive margin accounts for most of yearly variation in exports; gross contribution of destination and product extensive margins as important as gross contribution of entering and exiting firms.

\section{What drives export quality?}

Unit values of exports increase systematically with distance and tend to be higher in shipments to richer nations; higher-productivity firms tend to ship greater quantities at higher prices to a given market within product categories; high-productivity, high-quality firms are more able to serve difficult markets.

Role of export experience of managers acquired in previous firms for export performance and wages in current firm

Export experience in previous firms leads to higher export performance of current firm, and to sizeable wage premium for the manager; market specific export knowledge especially important for entry and saleries. 
Bastos and Dias (2013)

Amador and Opromolla

\section{Russia}

Schmeiser

(2012)

\section{Slovenia}

Damijan, Kostevc and Polanec

Damijan, Konings and Polanec

Damijan, Konings and Polanec (2014)
2005 and 2009; exports and import transactions of firms by product and destination market; matched with firm characteristics

1995-2005; universe of export transactions (products (HS4), values, quantities, destination countries) by firms; monthly data

2003-2004; exports by product, value, weight and destination

1994-2003; exports by product (value, quantity) and country, matched with firm characteristics

1994-2008; imports and exports at firm and product level (HS8, value and quantity), matched with firm characteristics and FDI data

1994-2008; imports and exports at firm-product-market level, matched with data on firm characteristics
Evolution of export performance over firm live cycle

Investigation of joint destination/ product strategies of exporters

Patterns of export entry and export expansion

Differences between new and incumbent exporters

Simultaneous export and import in identical products (pass-on trade, POT)

Effect of net and gross churning in imported varieties of capital and intermediate goods on firms export scope and productivity finds that, while continuing exporters enter new markets mainly by selling old products, new exporters access

new destinations mainly by exporting new products.

As firms age, the distribution of employment, export revenue, number of destinations and exported products shift progressively to the right.

Large share of export growth due to incumbent exporters entering new destinations; new exporters istics similar to domestic market.

Access to financing may account for an important part of observed differences in the extensive margins of exports between new and incumbent exporters

On average, $70 \%$ of all exporting firms engage in POT. Use of POT increasing in firm size, product diversification, multinational status, firm productivity and profitability.

Average firm changes about one-quarter of imported and exported product-markets every year, gross churning in terms of added and dropped productmarkets almost three times higher. Churning in imported varieties important for productivity growth. enter large countries and destinations with character- 
De Lucio, MinguezFuentes, Minondo and Requena-Silvente

Esteve-Pérez, Requena-Silvente and Pallardó-Lopez (2013)

Sweden

Andersson, Lööf and Johansson (2008)

1997-2004; exports and imports by firms by product (CN8) and country, value and weight; matched with firm characteristics and information on education of employees

Jienwatcharamongkhol 1997-2006; export value and weight (2014) by firm, product (HS8) and destination, matched with firm and destination characteristics

Gullstrand and

Persson

(2015)

Turkey

Lo Turco and Maggioni

(2013)
1997-2007; exports and imports, values and countries by firms

1997-2006; firm level data on export status, volume of exports, exported products, destinations;

matched with firm characteristics
1997-2007; exports by firm-productdestination (firms from food industry) matched with firm characteristics
Contribution of extensive (number of trading firms, products, countries) and variation in average value of trade flows of existing trade intensive (surviving trade relationship) relationships. In the longer run, both margins are margin to changes in exports and Imports

Duration of firms' trade relationships by destination and its determinants

Comprehensive description and analysis of international trading activities of firms

Analysis of effect of distance on export decision and export value at firm-product level for differentiated and non-differentiated products

Explanation of the empirical puzzle of importance of sunk costs of exports and short survival time of trade-flows

Substantial heterogeneity in terms of number of markets and number of products. Productivity premiums increase in number of markets and products. Two-way traders more productive than firms that only export or import.

Homogeneous products more sensitive to distance than differentiated products when controlling for annual shocks and industry heterogeneity. Learning effect from past trade experience.

Difference between core and peripheral export markets; firms tend to stay longer in their core markets, while exports to peripheral markets are much less long-term.

Role of Carry-along Trade (CAT) in exports - goods exported but not produced by a firm Large part of good exports recorded by manufacturing
firms are produced by other national actors.
2005-2009; exports (value and volume) at detailed product level; matched with production data at firm level 
Cebec

Demir and

Javorcik

(2014)

Cebeci and

Fernandes

(2015)

Lo Turco and

Maggioni

(2015)

Uruguay

Volpe Martincus and Carballo

Volpe Martincus,

Carballo and

Graziano

(2015)
2005-2010; exports by destination, value of transaction and year, matched with firm-level information

2004-2012; exports by product destination and financing terms

2002-2011; universe of export transactions (firm identifier, HS12, destination country, value, quantity)

2005-2009; exports and import by detailed product, matched with firm level information on production and balance sheet data

\section{0-2007; firm-level export data} by product (HS10) and destination, matched with information on export assistance received

2002-2011; universe of export transactions, firm ID, HS10 code, customs location, destination country, foreign buyer, transport mode, value, quantity, channel; plus precise information on actual time the transaction took to go through customs
Evaluation of the role of export destinations on firm performance (low income vs. high income destinations

Choice of payment method in exports Prevalence of exporter-financed exports increases with (open account, cash in advance, letter of credit) with focus on role of product differentiation

Microdynamics behind export boom Year-to-year aggregate export growth dominated from 2002-2008 and strong contraction by development in continuous exporters at destination $2008 / 2009$ and recovery thereafter

Causal effect of importing and exporting on introduction of new products and product scope

Effect of export promotion on entering new country and product markets

Effects of custom-related delays on firms' exports institutional quality in importing country; product differentiation reinforces positive effect of institutional quality.

Unlike exporting to high-income destinations, exporting to low-income destinations does not result in significantly higher firm TFP and wages. and product intensive margins. High degree of export entry and exit from year to year.

Produced exports important in spurring firm product scope and innovation. Importing only reinforces this effect when jointly undertaken with exporting. Exporting and two-way trading foster product quality upgrading.

Trade supporting activities have helped firm reach new destination countries and introduce new differentiated products.

Delays have a significant negative impact on firms exports along several dimensions; effects are more pronounces on sales to newer buyers. 
Bernard, Jensen, Redding and Schott (2007)

Bernard, Jensen and Schott (2009)

Bernard, Jensen, Redding and Schott (2009)

Bernard, Jensen, Redding and Schott (2010a) Redding and Schott (2010b)

Bernard, Redding and Schott (2011)
1992-2000; all international

trade transactions by product, value, quantity shipped, country, transport mode, and identifier of US firm

1993 and 2000; all trade transactions by firm-product-country-year and arm's length vs. intra-firm trade; matched with employment data

1993-2003; all international

trade transactions by U.S. firm, HS10 product, value, date, destination/ source country, and arm's length or related party transaction

2002; for each export and import transaction US firm, HS10 product, value, date, destination/source country, and arm's length or related party transaction. For imports identifier for foreign manufacturer or shipper

1997; import transactions, either arm's length or with related party (intra firm trade); country characteristics matched to data

1992 - 2004; all U.S. international trade transactions; exporting firm, HS10 product, value shipped, date of shipment, destination country
Descriptive evidence on extensive and intensive margins

Descriptive evidence on extensive and intensive margins; role of most globally engaged (MGE) firms that export and import and do so in part with related parties

Descriptive evidence on extensive and intensive margins across partner countries and over time. Response of margins of trade to macroeconomic shock (Asian crisis 1997) with diff-indiff approach.

Extend to which US exports and imports flow through wholesalers and retailers versus "producing and consuming" firms

Product and country determinants of intrafirm trade

General equilibrium model of multiproduct, multiple-destination firms with heterogeneity in ability across firms and in product attributes within firms. Test of core implications
International trade is extremely concentrated across firms; trade dominated by few multi-product exporters that export to many countries. Exporting firms share a variety of positive attributes with firms that are importers.

Trade is concentrated among a very small number of firms; most exporters and importers trade relatively few products with relatively small number of high-income countries; few large multi-product multi-country traders dominate exports and imports. MGE very influential in trade and employment.

Short-run changes in exports largely accounted for by the intensive margin; comparable results for imports. Dominance of the intensive margin in value terms in decline of exports to Asia in the crisis.

Pure wholesalers and retailers account for large shares of trading firms but relatively little value; most trade by firms that are producers and that are engaged in wholesale / retail, too. Differences by product type and market size.

Higher revealed product contractibility associated with less intrafirm trade. Increases in governance quality raise probability that foreign affiliates are present but are associated with lower shares of intrafirm trade.

Firms exporting many products also serve many export destinations and export more of a given product to a given destination. 
Kurz and Senses (2013)

1991-2005; exports and imports at firm level by product (HS10), value, and country of destination or origin; matched with firm characteristics

\section{Multi-country studies}

Malawi, Mali, Senegal and Tanzania

Cadot, lacovane, Pierola and Rauch (2011)

\section{5-2008 (Malawi and Mali)} 2000-2008 (Senegal),

2003-2008 (Tanzania); export

flows at transaction level (HS8

or HS10, destination market, value,

weight, port used, date)

\section{2 countries}

\section{Freund and}

Pierola

(2012)
2004-2008; World Bank Exporter Dynamics Database (EDD).

Universe of export transactions at exporter-product-destination-year level for firms

Direction and magnitude of association Relative to purely domestic firms, firms that only export between firm-level exposure to trade and volatility of employment growth wh that both export and import are less volatile, whereas firms that only import are more volatile. High degree of heterogeneity across trading firms in terms of duration of time and intensity of trade, number and type of traded products and number and characteristics of trading partners, all important for employment volatility.

Determinants of success and survival on an export market beyond the first year

Role of largest exporters for shaping trade patterns
High degree of experimentation at the extensive margin associated with low survival rates; survival probability rises with number of firms exporting the same product to the same destination from the same country, pointing to cross-firm synergies. More diversified firms more likely to survive in exporting.

Top 1 percent of exporters - export superstars dominate exports, cover about half of all exports on average in the 32 countries (top 10 percent cover 90 percent). 
Cebeci, Fernandes,
2003-2010; World Bank Exporter Dynamics Database (EDD).

Universe of export transactions at exporter-product-destination-year level of firms Freund and Pierola (2012)

Description of World Bank Exporter Dynamics Database (EDD) reporting exporter characteristics and measures of exporter growth based on firm level customs information by country.-year country-year-product and countryyear-destination

Assessment of extent of "export entrepreneurship" (advent of new exporting firms, new export products, new export market destinations)

and Gutierrez-Rocha (2013)

Costa Rica, Dominican

Repblic, Ecuador,

El Salvador, Guatemala

Mexico, Nicaragua,

Peru

005-2009; World Bank Exporter Dynamics Database (EDD).
Universe of export transactions at exporter-product-destination-year level for firms

Brazil, Chile Muendler

2000; Data o firms-destination markets - export products
Denmark, Norway

Arkolakis and
Comparable results on export participation, destination markets, and export products; comparison with earlier findings from France and USA
Larger or more developed economies have more exporters, larger and more diversified exporters, and lower entry and exit rates; expansion along intensive margin (exporter size) more important for export growth than entry of new exporters (extensive margin); exit and entry rates highly correlated; high importance of large multi-product firms.
Latin American and Caribbean region appears to be no less entrepreneurial in terms of the extensive margins of exports than comparator countries.
Only small number of firms ship to large number of markets; most firms ship to limited number of large markets. At a given destination there are only a few wide-scope and large-sales firms, but many narrowscope and small-sales firms. 
Carballo, Ottaviano and Volpe Martincus (2013)

2005-2008; data at exporterproduct-country-importer level; value and quantity of HS10 to each importing company

Ghana, Mali, Malawi

Senegal, Tanzania

\section{Jaud, Kukenova \\ 2000-2008; export data at \\ and Strieborny \\ firm-product-destination \\ (2013) \\ level (HS8), values and}

quantities; agri-food products

product level

\section{4 developing countries}

Jaud, Kiendrebeogo and Veganzones-

Varoudakis

(2015)
1997-2011; World Bank Exporter Dynamics Database (EDD).

Exported products at HS6-level, diversification measured by firm dynamics, product dynamics and destination dynamics
Provide a precise characterization of firms' export margins, across products, destination countries, and customers

Impact of financial development on long-term trade using measure of export-related financial needs at development.

Implications of financial vulnerability

for export diversificationin

developing economies
Number of buyers and distribution of sales across them systematically vary with characteristics of destination markets. Most firms trade with only very few buyers, number of buyers increase with size and accessibility of destinations.

Finance matters for sustainable export performance, as goods with higher export-related financial needs disproportionally benefit from better financial
Negative and economically large effect of financial vulnerability on export diversification.

Studies are listed by country covered in alphabetical order and chronologically by publication data within countries; studies covering multiple countries are listed at the end of the table in chronological order. CN refers to the Combined Nomenclature, HS to the Harmonized System of classification of goods. 


\section{References to the appendix table}

Abreha, Kaleb Girma, Valérie Smeets, and Frédéric Warzynsky (2013): Coping with the Crisis: Recent Evolution in Danish Firms' International Trade Involvement, 2000-2010. Aarhus University Economics Working Papers 2013-15.

Aisen, Ari, Roberto Álvarez, Andrés Sagner, and Javier Turén (2013): Credit conraction and international trade: Evidence from Chilean exporters. World Development 44, 212-224.

Albornoz, Facundo, Héctor F. Calvo Pardo, Gregory Corcos, and Emanuel Ornelas (2012): Sequential exporting. Journal of International Economics 88 (1) 17-31. Altomonte, Carlo and Gábor Békés (2010): Trade Complexity and Productivity. CeFiG Working Papers 12.

Álvarez, Roberto, Hasan Faruq, and Ricardo A. López (2010): Is Previous Export Experience Important for New Exports? Central Bank of Chile Working Paper 599.

Álvarez, Roberto and J. Rodrigo Fuentes (2011): Entry into Export Markets and Product Qualtiy. The World Economy 34, 1237-1262.

Álvarez, Roberto and Camila Sáez (2014): Post financial crisis and exports expansion: Micro-evidence from Chilean exporters. MPRA Munich Personal RePEc Archive Paper 60637.

Amador, Joao and Luca David Opromolla (2010): The Margins of Exports: Firms, Products and Destinations. Economics Bulletin (Banco de Portugal), Spring, 103-119.

Amador,Joao and Luca David Opromolla (2013): Product and destination mix in export markets. Review of World Economics 149 (1), 23-53. 
Amiti, Mary, Oleg Itskhoki, and Jozef Konings (2012): Importers, Exporters, and Exchange Rate Disconnect. National Bureau of Economic Research NBER Working Paper 18615.

Andersson, Martin, Hans Lööf, and Sara Johansson (2008): Productivity and International Trade: Firm Level Evidence from a Small Open Economy. Review of World Economics 144 (4), 776-801.

Ariu, Andrea (2012): Services versus goods trade: Are they the same? National Bank of Belgium NBB Working Paper 237.

Arkolakis, Costas and Marc-Andreas Muendler (2010): The Extensive Margin of Exporting Products: A Firm-level Analysis. National Bureau of Economic Research NBER Working Paper 16641.

Arkolakis, Costas and Marc-Andreas Muendler (2013): Exporters and Their Products: A Collection of Empirical Regularities. CESifo Economic Studies 59 (2), 223248.

Bai, Xue, Kala Krishna, and Hong Ma (2015): How You Export Matters: Export Mode, Learning and Productivity in China. National Bureau of Economic Research NBER Working Paper 21164.

Bas, Maria and Vanessa Strauss-Kahn (2010): Does importing more inputs raise exports? Firm level evidence from France. MPRA Munich Personal RePEC Archive Paper 27315.

Bastos, Paulo and Daniel A. Dias (2013): The life cycle of exporting firms. Mimeo.

Bastos, Paulo and Joana Silva (2010): The quality of a firm's exports: Where you export matters. Journal of International Economics 82 (2), 99-111.

Behrens, Kristian, Gregory Corcos, and Giordano Mion (2013): Trade Crisis? What Trade Crisis? Review of Economics and Statistics 95 (2), 702-709. 
Békés, Gábor and Balázs Murakösy (2012): Temporary trade and heterogeneous firms. Journal of International Economics 87, 232-246.

Békés, Gábor, Balázs Murakösy, and Péter Harasztosi (2011): Firms and products in international trade: Evidence from Hungary. Economic Systems 35 (1), 4-24.

Berman, Nicolas, Antoine Berthou, and Jérome Héricourt (2012): Export Dynamics and Sales at Home. Banque de France Document de Travail No 408.

Berman, Nicolas, Philippe Martin, and Thierry Mayer (2009): How do different exporters react to exchange rate changes? Theory, empirics and aggregate implications. Centre for Economic Policy Research CEPR Discussion Paper No. 7493 .

Bernard, Andrew B., Marco Grazzi, and Chiara Tomasi (2011): Intermediaries in international trade: Direct versus indirect modes of export. National Bureau of Economic Research NBER Working Paper 17711.

Bernard, Andrew B., J. Bradford Jensen, Stephen J. Redding, and Peter K. Schott (2007): Firms in International Trade. Journal of Economic Perspectives 21 (3), 105-130.

Bernard, Andrew B., J. Bradford Jensen, Stephen J. Redding, and Peter K. Schott (2009): The Margins of US Trade. American Economic Review Papers \& Proceedings 99 (2), 487-493.

Bernard, Andrew B., J. Bradford Jensen, Stephen J. Redding, and Peter K. Schott (2010a): Wholesalers and Retailers in US Trade. American Economic Review Papers \& Proceedings 100 (2), 408-413.

Bernard, Andrew B., J. Bradford Jensen, Stephen J. Redding, and Peter K. Schott (2010b): Intrafirm Trade and Product Contractability. American Economic Review Papers \& Proceedings 100 (2), 444-448. 
Bernard, Andrew B., J. Bradford Jensen, and Peter K. Schott (2009): Importers, Exporters, and Multinationals. A Portrait of Firms in the U.S. that Trade Goods. In Timothy Dunne, J. Bradford Jensen, and Mark J. Roberts (Ed.), Producer Dynamics. New Evidence from Micro Data. Chicago and London: University of Chicago Press, p. 513-555.

Bernard, Andrew B., Renzo Massari, Jose-Daniel Reyes, and Daria Taglioni (2013): Exporter Dynamics, Firm Size and Firm Growth, and Partial Year Effects. World Bank Policy Research Working Paper 6711.

Bernard, Andrew B., Andreas Moxnes, and Karen Helene Ulltveit-Moe (2013): Twosided Heterogeneity and Trade. Mimeo.

Bernard, Andrew B., Stephen J. Redding, and Peter K. Schott (2011): Multiproduct Firms and Trade Liberalization. Quarterly Journal of Economics 126 (3), 1271 1318.

Bernard, Andrew B., Ilke Van Beveren, and Hylke Vandenbussche (2010): Multiproduct exporters, carry-along trade and the margins of trade. National Bank of Belgium NBB Working Paper Series No. 203.

Bernard, Andrew B., Ilke Van Beveren, and Hylke Vandenbussche (2014): Multiproduct exporters and the margins of trade. Japanese Economic Review 65 (2), 142-157.

Bernini, Michele, Sarah Guillou, and Flora Bellone (2013): Firms Leverage and Export Quality: Evidence from France. Ofce Document de travail 2013-13.

Berthou, Antoine and Lionel Fontagné (2013): How do Multiproduct Exporters React to a Chanve in Trade Costs? Scandinavian Journal of Economics 115 (2), 326-353.

Berthou, Antoine and Vincent Vicard (2015): Firms' Export Dynamics: Experience Versus Size. The World Economy (in press). 
Biscourp, Pierre and Francis Kramarz (2007): Employment, skill structure and international trade: Firm-level evidence for France. Journal of International Economics 72 (1), 22-51.

Blum, Bernardo S., Sebastian Claro, and Ignatius J. Horstmann (2009): Intermediation and the Nature of Trade Costs: Theory and Evidence. Mimeo.

Blum, Bernardo S., Sebastian Claro, and Ignatius J. Horstmann (2010): Facts and Figures on Intermediated Trade. American Economic Review Papers \& Proceedings 100 (2), 419-423.

Blum, Bernardo S., Sebastian Claro, and Ignatius J. Horstmann (2013): Occasional and perennial exporters. Journal of International Economics 90 (1), 65-74.

Blyde, Juan, Gonzalo Iberti, and Micaela Mussini (2015): When does Innovation Matter for Exporting? MPRA Munich Personal RePEc Archive Paper 61574.

Bourgeon, Pauline, Jean-Charles Bricogne, and Guillaume Gaulier (2012): Financing time to trade: Evidence from French firms. Documents de Travail du Centre D’Economie de la Sorbonne 2012.16.

Brambilla, Irene, Daniel Lederman, and Guido Porto (2012): Exports, Export Destinations, and Skills. American Economic Review 102 (7), 3406-3438.

Bricogne, Jean-Charles, Lionel Fontagné, Guillaume Gaulier, Daria Taglioni, and Vincent Vicard (2010): Exports and Sectoral Financial Dependence. Evidence on French Firms During the Great Global Crisis. European Central Bank Working Paper Series No 1227.

Buono, Ines and Harald Fadinger (2012): The micro dynamics of exporting: evidence from French firms. Banca D'Italia Temi di Discussione Number 880.

Cadot, Olivier, Leonardo lacovone, Denisse Pierola, and Ferdinand Rauch (2011): Success and Failure of African Exporters. The World Bank Policy Research Paper 5657. 
Carballo, Jerónimo, Gianmarco I. P. Ottaviano, and Christian Volpe Martincus (2013): The Buyer Margins of Firms' Exports. Centre for Economic Performance CEP Discussion Paper No. 1234.

Casas, Camila, Federico J. Díez, and Alejandra González (2015): Productivity and Export Market Participation: Evidence from Colombia. Banco de la Republica Colombia, Borradores de Economía Núm. 876.

Cebeci, Tolga (2014): Impact of Export Destinations on Firm Performance. The World Bank Policy Research Paper 6743.

Cebeci, Tolga and Ana M. Fernandes (2015): Microdynamics of Turkey's Export Boom in the 2000s. The World Economy (in press).

Cebeci, Tolga, Ana M. Fernandes, Caroline Freund, and Matha Denisse Pierola (2012): Exporter Dynamics Database. World Bank Policy Research Working Paper 6229.

Corcos, Gregory, Delphine M. Irac, Giordano Mion, and Thierry Verdier (2013): The Determinants of Intrafirm Trade: Evidence from French Firms. Review of Economics and Statistics 95 (3), 825-838.

Costa, Stefano, Carmine Pappalardo, and Claudio Vicarelli (2014): Financial crisis, internationalization choices and Italian firm survival. MPRA Munich Personal RePEc Archive Paper 54107.

Creusen, Harold, Henk Kox, Arjan Lejour, and Roger Smeets (2011): Exploring the Margins of Dutch Exports: A Firm-Level Analysis. De Economist 159 (4), 413434.

Creusen, Harold and Arjan Lejour (2011): Uncertainty and the export decisions of Durch firms. FIW Working Paper No. 69.

Crozet, Matthieu, Guy Lalanne, and Sandra Poncet (2013): Wholesalers in international trade. European Economic Review 58 (1), 1-17. 
Cuyvers, Ludo, Emmanuel Dhyne, and Reth Soeng (2010): The effect of internationalisation on domestic labour demand by skills: Firm-level evidence for Belgium. National Bank of Belgium Working Paper Research No 206.

Damijan, Joze P., Jozef Konings, and Saso Polanec (2013): Pass-on trade: why do firms simultaneously engage in two-way trade in the same varieties? Review of World Economics 149 (1), 85-111.

Damijan, Joze P., Jozef Konings, and Saso Polanec (2014): Import Churning and Export Performance of Multi-product Firms. The World Economy 37 (11), 1483-1506.

Damijan, Joze P., Crt Kostovc, and Saso Polanec (2011): Export Strategies of New Exporters: Why is Export Expansion Along the Extensive Margins so Sluggish? LICOS Discussion Paper Series 277/2011.

De Lucio, Juan, Raúl Minguez-Fuentes, Asier Minondo, and Francisco RequenaSilvente (2011): The extensive and intensive margins of Spanish trade. International Review of Applied Economics 25 (5), 615-631.

Demir, Banu and Beata Javorcik (2014): Grin and Bear It: Producer-Financed Exports from an Emerging Market. Mimeo.

Duvalaix-Treguer, Sabine, Charlotte Emlinger, Carl Gaigne, and Karine Latouche (2015): Quality and Export Performance: Evidence from cheese industry. Mimeo.

Eaton, Jonathan, Marcela Eslava, Maurice Kugler, and James Tybout (2007): Export Dynamics in Colombia: Firm-Level Evidence. National Bureau of Economic Research NBER Working Paper Series 13531.

Eaton, Jonathan, Samuel Kortum, and Francis Kramarz (2004): Dissecting Trade: Firms, Industries, and Export Destinations. American Economic Review Papers \& Proceedings 94 (2), 150-154. 
Eaton, Jonathan, Samuel Kortum, and Francis Kramarz (2011): An Anatomy of International Trade: Evidence from French Firms. Econometrica 79 (5), 14531498.

Eriksson, Tor, Valérie Smeets, and Frédéric Warzynski (2009): Small Open Economy Firms in International Trade: Evidence from Danish Transactions-level Data. Aarhus University Department of Economics Working Paper 09-7.

Esteve-Pérez, Silviano, Francisco Requena-Silvente, and Vincente J. Pallardó-Lopez (2013): The Duration of Firm-Destination Export Relationships: Evidence from Spain, 1997-2006. Economic Inquiry 51 (1), 159-180.

Fabling, Richard, Arthur Grimes, and Lynda Sanderson (2012): Whatever next? Export market choices of New Zealand firms'. Papers in Regional Science 91 (1), 137-159.

Fabling, Richard and Lynda Sanderson (2010): Entrepreneurship and aggregate merchandise trade growth in New Zealand. Journal of International Entrepreneurship 8 (2), 182-199.

Fan, Haichao, Edwin L.-C. Lai, and Yao Amber Li (2012): Credit Constraints, Quality, and Export Prices: Theory and Evidence from China. MPRA Munich Personal RePEC Archive Paper 40857.

Fernandes, Ana M., Daniel Lederman, and Mario Gutierrez-Rocha (2013): Export Entrepreneurship and Trade Structure in Latin America during Good and Bad Times. The World Bank Policy Research Paper 6413.

Freund, Caroline and Martha Denisse Pierola (2010): Export Entrpreneurs. Evidence from Peru. The World Bank Policy Research Working Paper 5407.

Freund, Caroline and Martha Denisse Pierola (2012): Export Superstars. The World Bank Policy Research Working Paper 6222. 
Giri, Rahul, Enrique Seira, and Kensuke Teshima (2013): Exporters during the Trade Collapse: The (Surprising) Resiliency of the Small Exporter. Mimeo.

Görg, Holger, Richard Kneller, and Balázs Muraközy (2012): What makes a successful export? Evidence from firm-product-level data. Canadian Journal of Economics 45 (4), 1332-1368.

Goldberg, Pinelopi, Amit Khandewal, Nina Pavnik, and Petia Topalova (2009): Trade Liberalization and New Imported Inputs. American Economic Review Papers \& Proceedings 99 (2), 494-500.

Goldberg, Pinelopi Koujianou, Amit Kumar Khandewal, Nina Pavnik, and Petia Topalova (2010): Imported Intermediate Inputs and Domestic Product Growth: Evidence from India. Quarterly Journal of Economics 125 (4), 1727-1767.

Gopinath, Gita and Brent Neiman (2011): Trade Adjustment and Productivity in Large Crises. National Bureau of Economic Research NBER Working Paper Series 16958.

Gullstrand, Joakim and Maria Persson (2015): How to combine high sunk costs of exporting and low export survival. Review of World Economics (in press).

Halpern, László, Miklós Koren, and Ádám Szeidl (2005): Imports and Productivity. Mimeo.

Halpern, László and Balázs Murakösy (2011): Firm Size and Extensive Margin: Hungarian Exports. Economic and Business Review 13 (1-2), 27-50.

Halpern, László and Balázs Murakösy (2012): Innovation, productivity and exports: the case of Hungary. Economics of Innovation and New Technology 21 (2), $151-173$

Ibsen, Rikke, Frederic Warzynski, and Niels Westergard-Nielsen (2009): Employment Growth and International Trade: A Small Open Economy Perspective. Department of Economics Working Paper 09-9. 
Jaud, Mélise, Youssouf Kiendrebeogo, and Marie-Ange Veganzones-Varoudakis (2015): Financial Vulnerability and Export Dynamics. Mimeo.

Jaud, Melise, Madina Kukenova, and Martin Striborny (2013): Financial Development and Sustainable Exports: Evidence from Firm-Product Data. Lund University Department of Economics Working Paper 2013:14.

Jienwatcharamongkhol, Viroj (2014): Distance Sensitivity of Export: A Firm-Product Level Approach. Journal of Industry, Competition and Trade 14 (4), 531-554.

Koenig, Pamina, Florian Mayneris, and Sandra Poncet (2010): Local export spillovers in France. European Economic Review 54 (4), 622-641.

Kramarz, Francis (1998): International Competition, Employment, and Wages: The microeconometrics of international trade. INSEE-CREST mimeo.

Kurz, Christopher and Mine Z. Senses (2013): Importing, Exporting and Firm-Level Employment Volatility. Federal Reserve Board Finance and Economics Discussion Series 2013-44.

Lederman, Daniel, Andrés Rodríguez-Clare, and Daniel Yi Xu (2011): Entrepreneurship and the Extensive Margin in Export Growth: A Microeconomic Accounting of Costa Rica's Export Growth during 1997-2007. The World Bank Economic Review 25 (3), 543-561.

Lo Turco, Alessia and Daniela Maggioni (2013): CAT exports in Turkish manufacturing. Mimeo.

Lo Turco, Alessia and Daniela Maggioni (2015): Imports, Expots and the Firm Product Scope: Evidence From Turkey. The World Economy (in press).

Mangiarotti, Giovanni and Guy Schuller (2010): Luxembourg exports of goods at firm level. Working papers du STATEC, Economie et Statistique 45.

Manova, Kalina, Shang-Jin Wei, and Zhiwei Zhang (2013): Firm Exports and Multinational Activity under Credit Constraints. Mimeo. 
Manova, Kalina and Zhihong Yu (2012): Firms and Credit Constraints along the Value-Added Chain: Processing Trade in China. Mimeo.

Manova, Kalina and Zhiwei Zhang (2009a): China's Exporters and Importers: Firms, Products and Trade Partners. National Bureau of Economic Research NBER Working Paper Series 15249.

Manova, Kalina and Zhiwei Zhang (2009b): Export Prices and Heterogeneous Firm Models. National Bureau of Economic Research NBER Working Paper Series 15342.

Martin, Julien and Florian Mayneris (2015): High-end variety exporters defying gravity: Micro facts and aggregate implications. Journal of International Economics 96 (1), 55-71.

Martins, Pedro S. and Luca David Opromolla (2009): Exports, Imports and Wages: Evidence from Matched Firm-Worker-Product Panels. Institute for the Study of Labor IZA Discussion Paper No. 4646.

Martuscelli, Antonio and Gonzalo Varela (2015): Survival is for the Fittest. Export Survial Patterns in Georgia. World Bank Policy Research Working Paper 7161.

Masso, Jaan and Priit Vather (2015): Exporting and Productivity: The Effects of MultiMarket and Multi-Product Export Entry. Scottish Journal of Political Economy (in press).

Mayer, Thierry, Marc J. Melitz, and Gianmarco I. P. Ottaviano (2014): Market Size, Competition, and the Product Mix of Exporters. American Economic Review 104 (2), 495-536. 
Mayneris, Florian and Sandra Poncet (2011): Export performance of Chinese domestic firms: the role of foreign export spillovers. Institut de Recherches Ėconomiques et Sociales de L'Université catholique de Louvain Discussion Paper 2011-3.

Meinen, Philipp (2011): Sunk Costs of Exporting and the Destination Market. Evidence from Denmark. Mimeo.

Mion, Giordano and Luca David Opromolla (2012): Managers' Mobility, Trade Performance, and Wages. Momeo.

Mion, Giordano and Linke Zhu (2010): Import Competition from and Outsourcing to China: A Curse or Blessing for Firms? Centre for Economic Performance CEP Discussion Paper No 1038.

Molina, Danielken and Marc-Andreas Muendler (2013): Preparing to Export. National Bureau of Economic Research NBER Working Paper Series 18962.

Moxnes, Andreas (2010): Are sunk costs in exporting country specific? Canadian Journal of Economics 43 (2), 467-493.

Muraközy, Balázs (2012): Margins of Hungarian exports during crisis. EFIGE working papers 53.

Muraközy, Balázs and Gábor Békés (2009): Temporary Trade. Institute of Economics, Hungarian Academy of Sciences, Discussion Papers MT-DP2009/9.

Muuls, Mirabelle (2008): Exporters and credit constraints. A firm-level approach. National Bank of Belgium Working Paper No 139.

Muuls, Mirabelle (2015): Exporters, importers and credit constraints. Journal of International Economics 95 (2), 333-343.

Muuls, Mirabelle and Mauro Pisu (2009): Imports and Exports at the Level of the Firm: Evidence from Belgium. The World Economy 32 (5), 692-734. 
Pisu, Mauro (2008a): Job creation, job destruction and firms' international trade involvement. National Bank of Belgium Working Paper No 130.

Pisu, Mauro (2008b):Export destinations and learning-by-exporting: Evidence from Belgium. National Bank of Belgium Working Paper No 140.

Raff, Horst and Joachim Wagner (2014): Foreign Ownership and the Extensive Margins of Exports: Evidence for Manufacturing Enterprises in Germany. The World Economy 37 (5), 579-591.

Rahu, Siim (2015): The Role of Uncertainty for Export Survival: Evidence from Estonia. The University of Tartu FEBA Working Paper.

Roberts, Mark J., Daniel Yi Xu, Xiaoyan Fan, and Shengxing Zhang (2011): Demand, Cost, and Profitability Across Chinese Exporting Firms. Mimeo.

Schmeiser, Katherine N. (2012): Learning to export: Export growth and the destination decision of firms. Journal of International Economics 87 (1), 89-97.

Schminke, Annette D. and Johannes van Biesebroeck (2013): Evaluation of export promotion policies in Belgium. Mimeo.

Secchi, Angelo, Federico Tamagni, and Chiara Tomasi (2014): The micro patterns of export diversification under financial constraints. Industrial and Corporate Change 23 (6), 1595-1622.

Smeets, Valerie and Frederic Warzynski (2013): Estimating productivity with multiproduct firms, pricing heterogeneity and the role of international trade. Journal of International Economics 90 (2), 237-244.

Stirböck, Claudia and Jürgen Kähler (2012): Trading structure and diversity of German firms in the light of EU enlargement: How do importers differ from exporters? Mimeo.

Tamagni, Federico (2013): Exporting under financial constraints: margins, switching dynamics and prices. Mimeo. 
Tovar, Jorge and Luis Roberto Martínez (2011): Diversification, Networks and the Survival of Exporting Firms. Universidad de los Andes Facultad de Economia Documentos CEDE 8.

Utar, Hale (2012): When the Floodgates Open: Evidence from the Response of Danish Textile and Apparel Industry to Lifting Trade Restrictions on Chinese Goods. Mimeo.

Utar, Hale (2013): Characteristics of International Trade Intermediaries and Their Location in the Supply Chain. Mimeo.

Vannoorenberghe, Gonzague, Zheng Wang, and Zhihong Yu (2014): Volatility and Diversification of Exports: Firm-Level Theory and Evidence. CESifo Working Papers No. 4916.

Volpe Martincus, Christian and Jerónimo Carballo (2008): Is export promotion effective in developing countries? Firm-level evidence on the intensive and extensive margins of exports. Journal of International Economics 76 (1), 89106.

Volpe Martincus, Christian and Jerónimo Carballo (2010): Entering new country and product markets: does export promotion help? Review of World Economics $146(3), 437-467$.

Volpe Martincus, Christian, Jerónimo Carballo, and Alejandro Graziano (2015): Customs. Journal of International Economics 96 (1), 119-137.

Wagner, Joachim (2012a): German multiple-product, multiple destination exporters: Bernard-Redding-Schott under test. Economics Bulletin 32 (2), 1708-1714.

Wagner, Joachim (2012b): Trading many goods with many countries: Exporters and Importers from German manufacturing industries. Review of Economics 63 (2), 170-186. 
Wagner, Joachim (2012c): Productivity and the extensive margins of trade in German manufacturing firms: Evidence from a non-parametric test. Economics Bulletin 32 (4), 3061-3070.

Wagner, Joachim (2013a): Are low-productive exporters marginal exporters? Evidence from Germany. Economics Bulletin 33 (1), 467-481.

Wagner, Joachim (2013b): Extensive margins of imports in the great import recovery in Germany, 2009/2010. Economics Bulletin 33 (4), 2732-2743.

Wagner, Joachim (2014a): Low-productive exporters are high-quality exporters. Evidence from Germany. Economics Bulletin 34 (2), 745-756.

Wagner, Joachim (2014b): What makes a high-quality exporter? Evidence from Germany. Economics Bulletin 34 (2), 865-874.

Wagner, Joachim (2014c): The Role of Extensive Margins of Exports in The Great Export Recovery in Germany, 2009/2010. Jahrbücher für Nationalökonomie und Statistik / Journal of Economics and Statistics 234 (4), 518-526.

Wagner, Joachim (2014d): Exports and firm profitability: Quality matters! Economics Bulletin 34 (3), 1644-1652.

Wagner, Joachim (2014e): Extensive margins of imports, productivity and profitability: First evidence for manufacturing enterprises in Germany. Economics Bulletin 34 (3), 1669-1678.

Wagner, Joachim (2014f): Is export diversification good for profitability? First evidence for manufacturing enterprises in Germany. Applied Economics 46 (33), 4083-4090.

Wagner, Joachim (2014g): A note on the granular nature of imports in German manufacturing industries. Review of Economics 65 (3), 241-252. 
Wagner, Joachim (2014h): A note on quality of a firm's exports and distance to destination countries: First evidence from German. University of Lüneburg Working Paper Series in Economics No. 302.

Wagner, Joachim (2015a): Credit constraints and margins of import: first evidence for German manufacturing enterprises. Applied Economics 47 (5), 415-430.

Wagner, Joachim (2015b): A note on firm age and the margins of imports: first evidence from Germany. Applied Economics Letters 22 (9), 679-682.

Wagner, Joachim (2015c): A Note on Firm Age and the Margins of Exports: First Evidence from Germany. The International Trade Journal 29 (2), 93-102.

Wagner, Joachim (2015d): Still different after all these years. Extensive and intensive margins of exports in East and West German manufacturing enterprises. University of Lüneburg Working Paper Series in Economics No. 313 (forthcoming, Jahrbücher für Nationalökonomie und Statistik / Journal of Economics and Statistics).

Wagner, Joachim (2015e): Credit constraints and the extensive margins of exports: First evidence for German manufacturing. University of Lüneburg Working Paper Series in Economics No. 336.

Wang, Zheng and Zhihong Yu (2011): Trading Partners, Traded Products, and Firm Performance: Evidence from China's Exporter-Importers. University of Nottingham GEP Research Paper Series 2011/13.

Yu, Miaojie and Jin Li (2014): Imported Intermediate Inputs, Firm Productivity and Product Complexity. Japanese Economic Review 65 (2), 178-192. 